\title{
Manzanares Valley (Madrid, Spain): A good country for Proboscideans and Neanderthals
}

\author{
Joaquín Panera a, *, Susana Rubio-Jara a, José Yravedra ${ }^{b}$, Hugues-Alexandre Blain ${ }^{\text {c, d }}$, \\ Carmen Sesé ${ }^{e}$, Alfredo Pérez-González \\ a Instituto de Evolución en Africa (I.D.E.A.), Museo de San Isidro, Plaza de San Andrés 2, 28005 Madrid, Spain \\ b Departamento de Prehistoria, Universidad Complutense de Madrid, Ciudad Universitaria s/n, 28040 Madrid, Spain \\ ${ }^{\mathrm{c}}$ Institut Català de Paleoecologia Humana i Evolució Social (I.P.H.E.S.), C/ Escorxador s/n, E-43003 Tarragona, Spain \\ d Área de Prehistoria, Universitat Rovira i Virgili (U.R.V.), Avinguda de Catalunya 35, E-43002 Tarragona, Spain \\ e Departamento de Paleobiología, Museo Nacional de Ciencias Naturales, C.S.I.C., C/ José Gutiérrez Abascal 2, E-28006 Madrid, Spain \\ ${ }^{\mathrm{f}}$ Centro Nacional de Investigación sobre la Evolución Humana (C.E.N.I.E.H.), Paseo Sierra de Atapuerca, s/n, 09002 Burgos, Spain
}

\section{A R T I C L E I N F O}

\section{Article history:}

Available online $\mathrm{xxx}$

\begin{abstract}
A B S T R A C T
This paper presents the findings from four sites with proboscidean remains associated with Middle Palaeolithic stone tools from the Manzanares Valley Complex Terrace of Butarque (CTB), which has been dated to between the final Middle Pleistocene (MIS 6, 190-130 ka) and the early Late Pleistocene (MIS 5, 130-74-71 ka). We review the direct and indirect evidence of proboscidean exploitation in the Middle Paleolithic sites of Europe, and provide information on Lower Paleolithic European sites with proboscidean remains and stone tools. Geological, chronological, bio-stratigraphic and climatic data of the CTB are provided, and the sites with proboscidean remains and Middle Palaeolithic stone tools are described in detail.

Systematic exploitation of large mammals during the Middle Palaeolithic, and even their regular hunting, is widely accepted. However, the exploitation of proboscideans is not as evident in the archaeological record of this period. The exploitation of proboscideans cannot be considered as merely occasional before the Upper Palaeolithic, and although there is more evidence of the exploitation of these mega-herbivores during the Lower than during the Middle Palaeolithic, the discoveries from the Manzanares Valley state that, at least in this area, proboscideans continued to play an important role with regards to the exploitation of the environmental resources.
\end{abstract}

(c) 2013 Elsevier Ltd and INQUA. All rights reserved.

\section{Introduction}

Since the 18th Century, when elephant remains were first discovered along the River Manzanares as it passed through Madrid, recurrent discoveries of proboscideans have been found within the Pleistocene deposits of the river. Early identification of lithic tools and elephant bones were made at Cerro de San Isidro (Verneuil and Lartet, 1863; Prado, 1864), making this site one of the first in Europe where evidence of lithic industry was found in association with the remains of extinct fauna. Since then, several tens of sites containing remains of proboscideans have been found in the Manzanares Valley (Sesé and Soto, 2002).

\footnotetext{
* Corresponding author.

E-mail address: joaquin.panera@gmail.com (J. Panera).
}

Elephants modify their own ecosystems to such extent that many palaeoecologists consider them to be keystone (Owen-Smith, 1987, 1988, 1999; Robinson et al., 2003; Haynes, 2012). Groups of hunter-gatherers would have greatly benefited from observing elephant behaviour. It has even been suggested that elephants could have facilitated the exploitation of resources and the dispersal of human groups during the Pleistocene (Haynes, 2001, 2006). Furthermore, their disappearance has been interpreted as the direct cause of technological changes in the elaboration of lithic tools (Ben-Dor et al., 2011). Elephant movements are greatly influenced by the availability and dispersal of water (Stokke and Du Toit, 2002; Shannon et al., 2009). The most frequently visited ecosystems are riversides, where they can find not only water but also a variety of vegetation (Shannon et al., 2006). This is especially true for the cows, which are more restricted by the social and nutritional demands of the group (Duffy et al., 2011). Elephants know the location of water, mineral and plant resources, as well as 
gathering places, thanks to their complex mental maps (DouglasHamilton, 1972; Moss, 1982; Sukumar, 1989). These also provide them with easily traceable travel routes, which are followed by other mammals in their search for water during periods of drought, by carnivores in search of vulnerable prey and by human groups looking for the same resources. Additionally, by looking at their excrement, these human groups can infer relevant information such as their size, age, speed and health status (Haynes, 2006). Moreover, these routes connect strategic landmarks and are repeatedly used on a seasonal basis, as it has been suggested by the discovery of mammoth tracks through $60 \mathrm{~cm}$ of the Aeolian sediments in a paleovalley in Alberta, Canada. AMS obtained dates show that herds of mammoths followed the same trails for at least 200 years (McNeil et al., 2005).

Riverside ecosystems form authentic ecological corridors that connect different ecosystems and facilitate the movement of several vertebrate species (Forman, 1995). This becomes obvious towards the final reach of the River Manzanares Valley, where the river runs through a gypsum area whose saline substrate restricts the development of animal and plant species. Such an ecosystem contrasts with the highly varied biodiversity that can be observed at the riverbanks of the River Manzanares. This would have been even greater during the Pleistocene, when the landscape had not yet been changed by humans. This biodiversity could be one of the reasons why the area was regularly visited by elephants and hominins throughout the Pleistocene, as tens of proboscidean bone remains and Palaeolithical sites recorded throughout the river terraces have revealed (Panera and Rubio-Jara, 2002; Rubio-Jara, 2011).

The association between lithic tools and proboscidean remains has been a recurrent topic within Palaeolithic research (Villa, 1990; Haynes, 1991; Martos, 1998; Gaudzinski et al., 2005; Mussi, 2005; Villa et al., 2005). Some authors have argued that it is not clear whether this association is the result of a particular relationship between humans and elephants, the result of a bias in preservation due to the size of these mega-herbivore remains, or that perhaps this relationship did not become well established until the Upper Palaeolithic (Frison and Todd, 1986; Frison, 1989; Fosse, 1998; Gaudzinski et al., 2005; Surovell and Waguespack, 2008). This view is currently under scrutiny, firstly due to the discovery of new sites and secondly because new analysis is being carried out on already known sites. This new data has increased the number of instances of the exploitation of proboscidean by humans during the Lower and Middle Palaeolithic (Mussi and Villa, 2008; Yravedra et al., 2010, 2012; Ben-Dor et al., 2011; Slimak et al., 2011; Germonpré et al., 2012; Rabinovich et al., 2012; Saccà, 2012; Smith, 2012).

A significant number of Lower Palaeolithic sites containing lithic industry and elephant remains have been found in the Manzanares Valley (Meléndez and Aguirre, 1958; Santonja et al., 1980; Baena Preysler et al., 2010). To the end of the Middle Pleistocene (MIS 6, 190-130 ka) and the early Late Pleistocene (MIS 5, 130-74 ka), the remains of proboscideans and lithic industry found in the Complex Terrace of Butarque (CTB), in some cases with cut and percussion marks or green-bone fractures (Rus and Vega Toscano, 1984; Manzano et al., 2010; Yravedra et al., 2012), show that elephants were consistently exploided as a resource during the Middle Palaeolithic. This paper highlights that during this period, the final reach of the River Manzanares Valley made up a network of different ecosystems, within which there was more than just an occasional relationship between Neanderthals and proboscideans.

\section{Neanderthal-Proboscidean relationship}

There is evidence from a number of Middle Palaeolithic sites that may suggest the hunting of proboscideans. The remains of twenty individuals of Mammuthus primigenius and several of Coelodonta antiquitatis from MIS 6 have been recorded at La Cotte de St Brelade, Jersey, Channel Islands. According to Scott (1980: 146), the animals, herded by a human group, were thrown over a granite promontory rock. At Lehringen, Germany, dated to the Eemian, a $281 \mathrm{~cm}$ by $2.5 \mathrm{~cm}$ spear was found in association with the remains of a 45 year-old elephant and 27 flakes, some of them Levallois, a number of which had been refitted (Movius, 1950; Adam, 1951; Tode, 1954; Thieme and Veil, 1985). However, the lack of photographic and drawing records has hindered the widespread acceptance of this theory (Gamble, 1999). Nevertheless, it has been pointed out that traditional hunting of African elephants was mainly carried out with spears (Hobley, 1903; Trilles, 1932; Janmart, 1952; Bahuchet, 1987, cited in; Germonpré et al., 2012), and several 400 ka wooden spears found at Schöningen, Germany have been interpreted as unequivocal hunting tools which were used to hunt horses (Thieme, 2005). At the cave of Spy, Belgium, several cranial elements of short-aged $M$. primigenius were found in two main levels from MIS 3, 43 and 36 ka respectively. Having ruled out that these remains were the result of carnivore activity, Germonpré et al. (2012) suggest that the presence of newborn mammoths indicate selective hunting of young individuals by hominins, which would have occurred during the cold season. The skeletal remains of a c. 32-35 year-old female M. primigenius (Reggiani and Sala, 1992; Reggiani, 2005), found at Pagnano d'Asolo, Northeastern Italy, at the end of the 19th century and dated to MIS 4 or 3 (Venzo, 1977; Mussi and Villa, 2008) showed no evidence of either humanmade fractures or true cut marks. Apart from these remains, one non-retouched Levallois flake, one proximal flake fragment and three non-retouched Levallois points were found. One of these points showed an impact fracture at the tip, which has been interpreted as possible damage due to use as a spearhead, perhaps for killing the mammoth (Mussi and Villa, 2008). Villa and Lenoir (2009: 71) have pointed out the shortage of detailed studies about pointed forms (Mousterian points, elongated Mousterian points, convergent and déjeté scrapers) in Western Europe, which together with microwear analyses could add some relevant reasoning to this mega-herbivores hunting-scavenging debate. At Molodova I, Ukraine, in a Mousterian layer dated to MIS 3 containing 40,000 lithics and a minimum number of 15 mammoths, one projectile impact and a second possible one were observed in two mammoth ribs (Demay et al., 2012: 219). Finally in Santo Antao do Tojal, Portugal, two small flint flakes were located embedded in a femur fragment of Elephas (Palaeoloxodon) antiquus (Zbyszewski, 1943), although given the fluvial context of the site, they could well have been found in such a position due to post-depositional sedimentary processes (Sousa and Figueiredo, 2001).

Cut marks on mammoth bones have been described at La Cotte de St Brelade, at the proximal base of tusks, where the tusk meets the bone sheath of the skull (Scott, 1980, 1986); at Byzovaya, Russia, associated with lithic industry, dated to 28,500 BP (Slimak et al., 2011); one cut mark on an E. (Palaeoloxodon) antiquus bone was recorded from level XII of the Bolomor cave, Spain, and dated to 253 ka (Blasco and Fernández Peris, 2012, Table 5); at Molodova I, and at Kulna Cave, Czech Republic. These last two sites present a number of problems. At Molodova I, striations due to cutting processes have been recorded on three zygomatic bones, one cervical vertebra, nineteen rib body fragments (on both sides), three innominates, one femur, six long bone epiphyses and diaphysis and four indeterminate bones (Demay et al., 2012). If these striations were human-made, Molodova I would show a higher concentration of marks than all the other European Pleistocene sites put together. Thus, at least some of these marks could have been produced during excavation, as suggested by Nowell and d'Errico (2007). The cut marks depicted in Figure 12f of Demay et al. (2012: 223) are 
quite shallow, so despite being parallel they may be due to trampling. The marks shown on 12e are quite similar to those shown by Nowell and d'Errico (2007) to be the result of excavation tools, and $12 \mathrm{~d}$ is slightly open and wide, so care should be taken in ascertaining its origin. In Kulna cave, level 11 contained a microlithic assemblage from MIS 5 and the beginning of MIS 4, as well as the remains of $M$. primigenius (Moncel, 2001). According to Valoch (1988), a number of the mammoth bones show human-made cut marks, although these are currently being reviewed (Neruda, 2010).

Indirect evidence was also found at Gröbern, Germany, a site dated to MIS 5a. The almost complete skeleton of a 35-40 year-old E. (Palaeoloxodon) antiquus was found associated with 26 nonretouched flakes, mostly large (Mania et al., 1990), 9 of which showed use-wear traces, which suggest meat processing (Weber, 2000). At Spy and Saint-Césaire, France, stable isotope analyses carried out on Neanderthal remains have shown that consumption of extremely large herbivores such as mammoth and woolly rhinoceros played an important part in their diet (Bocherens, 2011).

Other sites have uncovered lithic tools and proboscidean remains with no evidence of human intervention. On the one hand, cut marks are rarely produced when defleshing or disarticulating elephants (Crader, 1983; Haynes and Krasinski, 2010). On the other hand, the association of lithic industry and proboscidean remains found in natural deposits with other large mammals could be accidental (Domínguez-Rodrigo, 2008). At Lynford, England, on the boundary between MIS 4/3, 11 individuals of $M$. primigenius (MNI), and artefacts of Mousterian of Acheulean Tradition have been interpreted as evidence of Neanderthal hunting and butchery (Schreve, 2006). However, the absence of cut or percussion marks on the mammoth remains, and the fact that they accumulated over a long period of time, by natural causes according to Smith (2012), and otherwise according to Brothwell and Schrve (2012), has limited the role of hominines to just occasional exploitation, although these authors do not rule out the possibility that the animals could have been hunted. An 18-20 year-old female individual of $E$. (Paleoloxodon) antiquus was found within the MiddleFinal Pleistocene deposits at Cava Campitello, Italy, as well as three flakes with remains of resin, which has been interpreted as hafting adhesive (Martini and Maza in Mussi, 2005: 413-414). Remains of six species of larger mammals including mammoth and 37 lithic artefacts probably dating to the MIS 6 were found at Ariendorf 2, Germany (Turner, 1997).

Finally, only a few Middle Palaeolithic sites show evidence of the intentional use of mammoth bones as raw-material. At the MIS 3 open-air site Salzgitter-Lebenstedt, Germany, 161 rib fragments, measuring from $10 \mathrm{~cm}$ to more than $1 \mathrm{~m}$ in length, from a minimum of 17 individuals of $M$. primigenius, were found. Twenty of these remains reveal human-made activities such as distal ends intentionally pointed and/or flattened (Gaudzinski, 1999). At Molodova I, in Layer 4, there are 5 areas, one of which is a circular structure constructed from specially selected mammoth bones (long and flat bones, tusks, connected vertebrae) measuring 5 by $8 \mathrm{~m}$ internally and 7 by $10 \mathrm{~m}$ externally (Chernysh, 1982; Demay et al., 2012). Tools and hearths were recorded at the centre of the structure, which has been variously interpreted as a dwelling, a hunting blind, natural accumulation, a symbolic structure, garbage around the settlement, or a wind break (Binford, 1983; Chernysh, 1989; Stringer and Gamble, 1993; Klein, 1999; Kolen, 1999; Hoffecker, 2002; Svoboda et al., 2005). Recently, Demay et al. (2012) suggested that this is a domestic structure, with a cooking activity area and flint workshops inside, and that Layer 4 of Molodova I could be a recurrent camp for numerous people. Other Neanderthal structures made of mammoth bones have been described as dwellings in Ripiceni-Izvor, Romania (Paunescu, 1992). However this site was excavated before the development of taphonomy and site formation process analysis. Additionally, at Molodova I Layer 4 the symbolic use of mammoth bones has been suggested as some examples were covered by ochre (Chernysh, 1982), and others show a series of parallel striations not characteristic of butchery activities. These marks have been identified as damage produced during the excavation process (Nowell and d'Errico, 2007).

\section{Geological setting of the Complex Terrace of Butarque (CTB) in the River Manzanares}

The area of study is a fluvial terrace located on the lower segment of the River Manzanares, to the southeast of Madrid, Spain (Fig. 1A, B). Geologically, this valley section lies in the continental tertiary basin of Madrid, in the area of transition between intermediate detritic facies (gravels and sands) and central facies (marls to evaporite-gypsum). This fluvial system is affected by synsedimentary subsidence due to the karstic dissolution of the gypsum in the substrate, a well-known process in the large tertiary continental basins in Spain, such as the Ebro basin (Benito et al., 1998, 2000), and the nearby valley of the River Jarama, where Pérez-González (1971) described these sinking phenomena due to adaptation or collapse for the first time (Portero and Pérez-González, 1990; PérezGonzález and Uribelarrea del Val, 2002). The main anomalous morphostratigraphical features that produce this type of subsidence include great thickening of fluvial deposits and superposition of the deposits correlative to different terrace levels, which can reach over 40 m (Pérez-González, 1971; Pérez-González et al., 2008).

Thus, upstream from the city of Madrid laid over siliciclastic bedrock, twelve levels of stepped alluvial terraces have been identified $(+8 \mathrm{~m},+10 \mathrm{~m},+12-15 \mathrm{~m},+18-20 \mathrm{~m},+25-30 \mathrm{~m},+35-$ $40 \mathrm{~m},+44-46 \mathrm{~m},+52-54 \mathrm{~m},+60 \mathrm{~m},+68-72 \mathrm{~m},+80-85$ and $95 \mathrm{~m}$ ), with a maximum thickness of 6-7 m (Pérez-González, 1994). Downstream, the terraces formed over evaporitic rocks $+25-30 \mathrm{~m},+18-20 \mathrm{~m}$ and $+12-15 \mathrm{~m}$, are overlapped and affected by the synsedimentary subsidence resulting in a huge thickness increase of tens of meters. These terraces constitute the so-called Terrace Complex of Butarque (CTB) (Goy et al., 1989). Silva (2003) names this as the Manzanares Complex Terrace (TCMZ). On this terrace, a large number of paleontological and archaeological sites have been excavated since the mid-20th century (Panera and Rubio-Jara, 2002). Some of these were buried under overbank facies composed of silty-clay, which are very common in these sedimentary environments.

The CTB sedimentation models have been addressed by Carrillo et al. (1978) and Arche (1983) at PRERESA, an open quarry front, $14 \mathrm{~m}$ in depth, where they have established up to five fluvial cycles, starting with deposits of gravel and channel sand, and ending with mud-floodplain facies, characteristic of meandering rivers. A minimum of five cycles have been acknowledged, although the final number may vary along the terraces due to autocyclic or allocyclic mechanisms. Up to six fining-upward cycles have been described on the left bank of the lower course of the River Manzanares, most of which contain Pleistocene faunal remains and lithic industry (Gaibar Puertas, 1974). At Los Estragales, the CTB is composed of two alluvial sequences that can reach up to $35 \mathrm{~m}$ in thickness, and are divided by substantial hiatus representing thousands of years (Pérez-González et al., 2008). The oldest sequence, which includes Middle Palaeolithic sites, consists of up to $8 \mathrm{~m}$ of mud featuring, to the top, a $\mathrm{Ck}$ nodular horizon over $1 \mathrm{~m}$ thick wherever it has not been eroded by channels of flint gravels and tertiary carbonates; the earlier sequence, overlying the first one, consists of several finingupwards sequences (Pérez-González et al., 2008). 


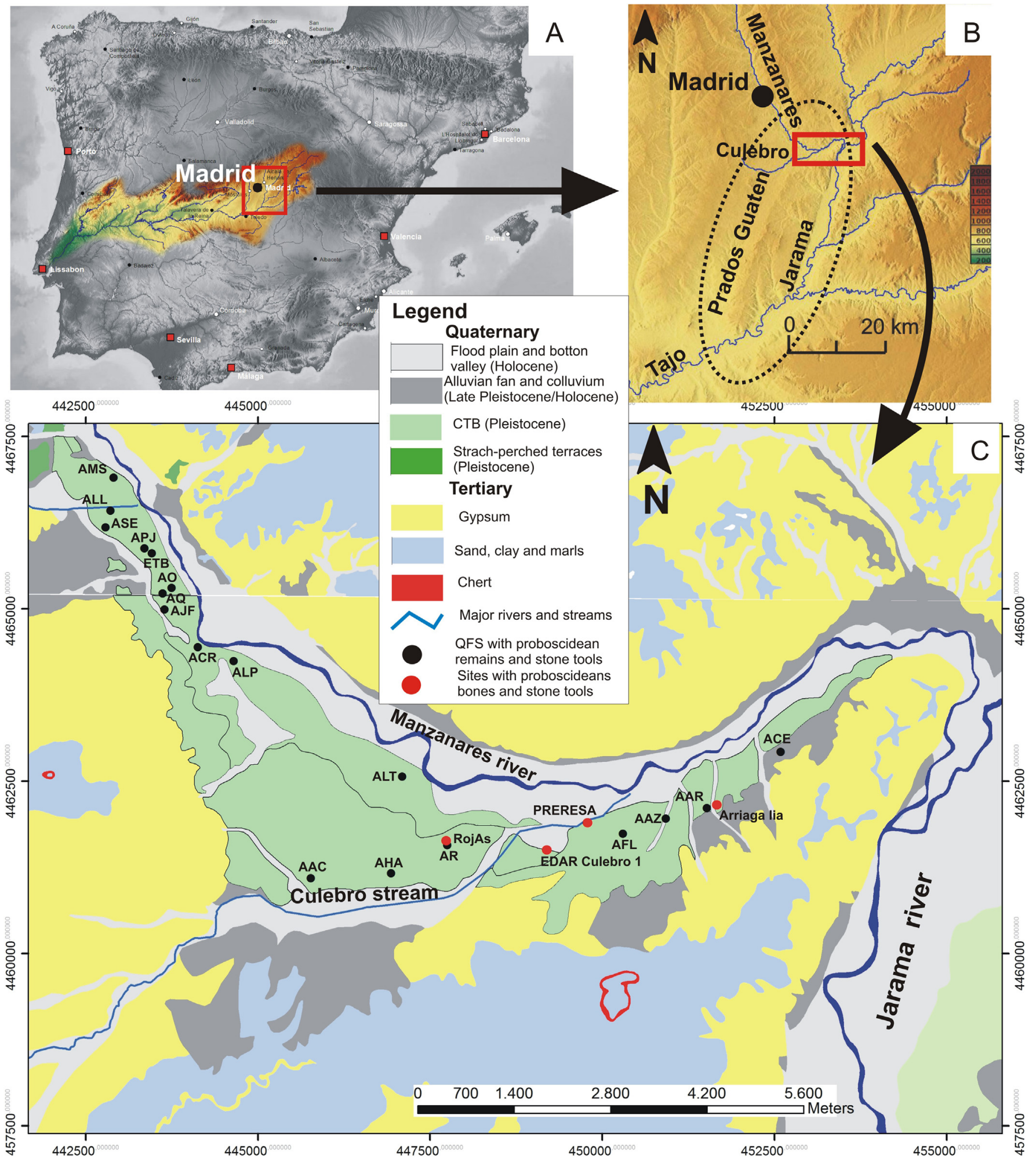

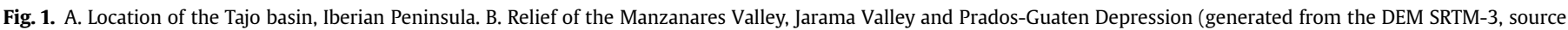

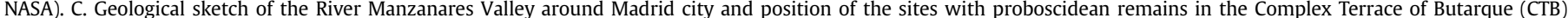

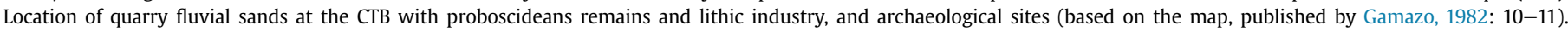

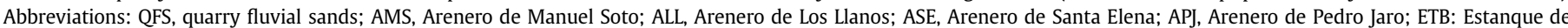

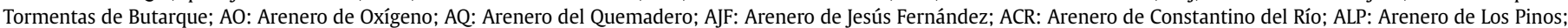

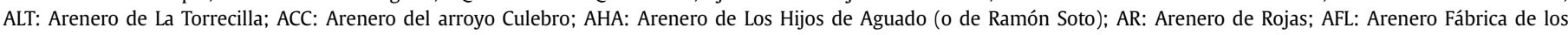
Ladrillos; AAZ: Arenero de Arcaraz; AAR: Arenero de Arriaga; ACE: Arenero de Casa Eulogio. 


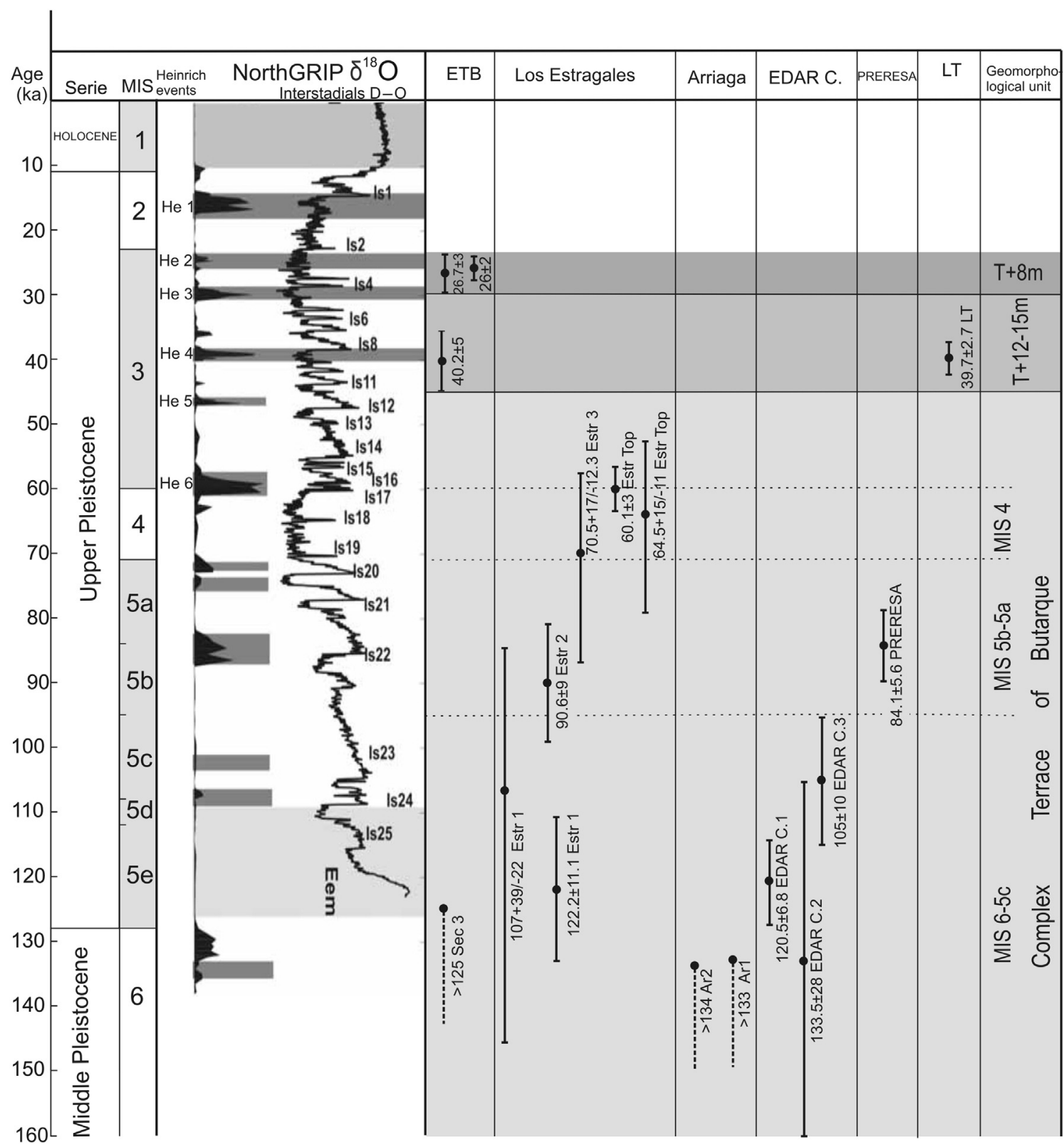

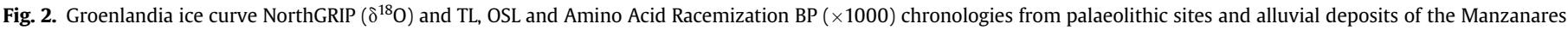

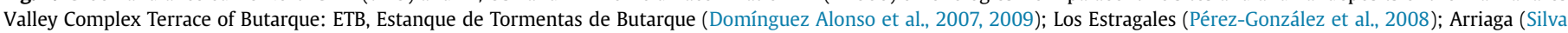
et al., 2012b); EDAR Culebro (Manzano et al., 2010; Silva et al., 2012a); LT, La Torrecilla (Pérez-González et al., 2008).

\section{CTB numerical time frame}

The availability of luminescence-based numerical dates, taken from four sites spread along the CTB, suggests that the visible extent of this deposit spans from MIS 6 to MIS 4 (Fig. 2). Two sites with remains of E. (Paleoloxodon) antiquus and Middle Palaeolithic industry fit into MIS 6. At the lower sequence of Estanque de Tormentas de Butarque, an assemblage of nearly 3000 pieces of lithic industry was discovered (Rubio-Jara, 2011) as well as a proboscidean tusk dated to final Middle Pleistocene according to micromammals (C. Laplana pers. comm). At Arriaga, remains of $E$. (Paleoloxodon) antiquus as well as lithic industry of the Middle Palaeolithic (Rus and Vega Toscano, 1984) have provided minimum TL dates of $133 \mathrm{ka}$ and 134 ka respectively
(Silva et al., 2012b). The species represented within the micromammal assemblage and especially the evolved stage of Microtus brecciensis and Arvicola aff. sapidus point to a date within the end of the Middle Pleistocene (Sesé and López Martínez, 2013).

With regard to the early MIS 5, a series of numerical dates associated with sites containing Middle Palaeolithic lithic industry and the remains of mammoth in one case, fit into this period. The top of the lower alluvial sequence of Los Estragales, which has been eroded by channels filled with flint gravels, tertiary carbonates and plentiful lithic industry (Rubio-Jara, 2011), provides two dates that overlie each other within MIS 5e, $107+39 /-22$ ka and $122.1 \pm 11.1$ ka (Pérez-González et al., 2008). At EDAR Culebro 1, where the remains of Mammuthus cf. intermedius as well as lithic 


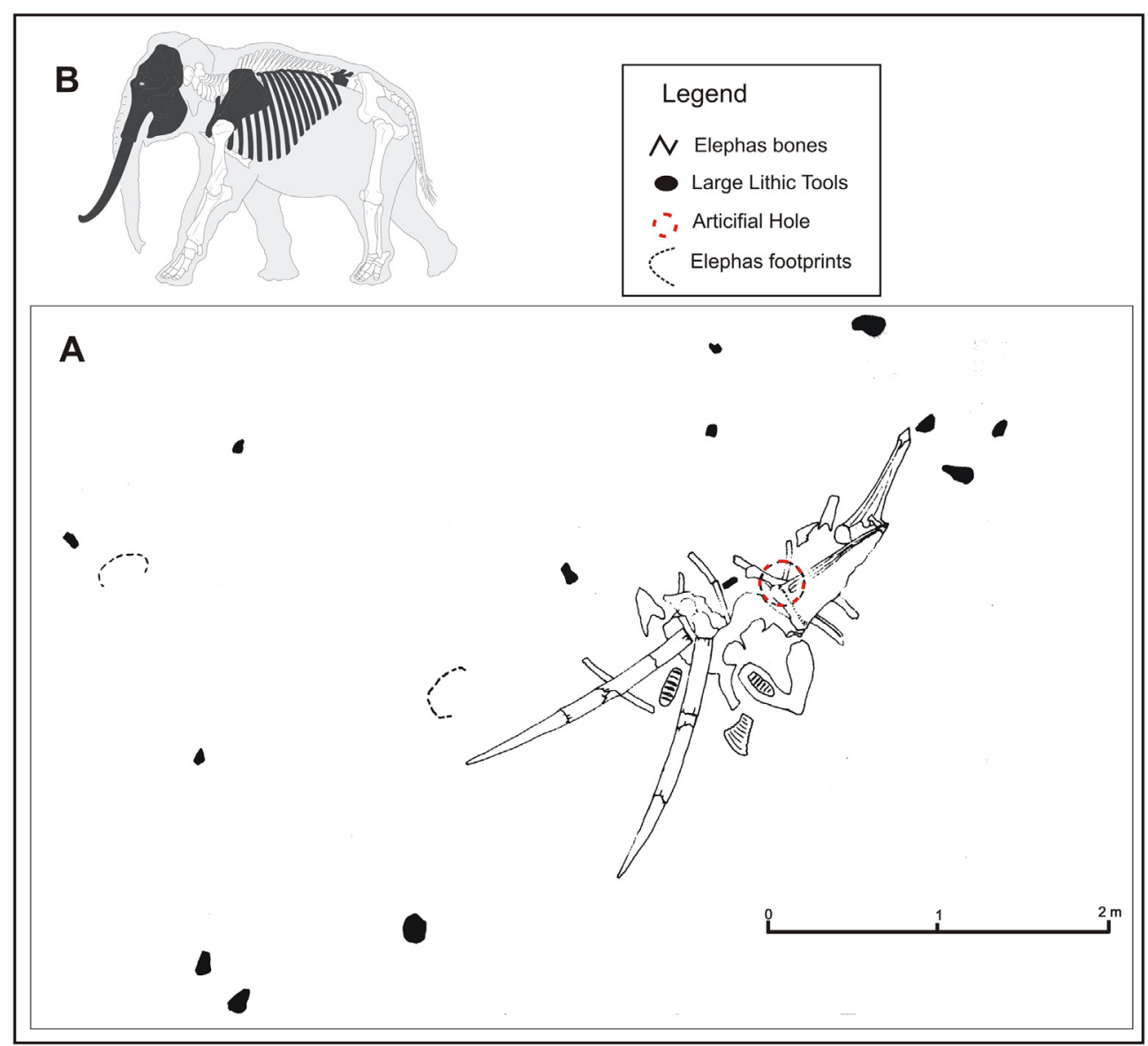

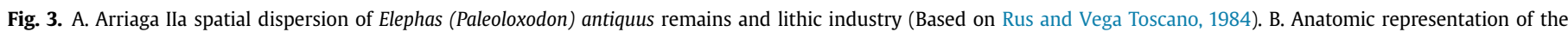
elephant remains uncovered at Arriaga Ila.

industry have been recorded, an OSL date of $120.541 \pm 6.851$ ka has been obtained (Manzano et al., 2010; Silva et al., 2012a). Additionally, Amino-Acid Racemization (AAR) techniques carried out on an Equus sp. molar have provided dates of $133 \pm 28$ and $105 \pm 10 \mathrm{ka}$ BP (Silva et al., 2012b).

The middle parts of the CTB outcrops fit chronologically between the MIS $5 \mathrm{c}$ and $5 \mathrm{a}$. The site of PRERESA, where proboscidean remains have been found alongside lithic industry (Rubio-Jara, 2011; Yravedra et al., 2012), has been dated to $84,126 \pm 5633 \mathrm{ka}$ by OSL (LDR). This date is consistent with the micromammals recorded from the site: the presence of Microtus cabrerae (descendant of the Middle Pleistocene M. brecciensis) and the evolved stage of this species as well as of Arvicola aff. sapidus suggests a Late Pleistocene date (Sesé and Sevilla, 1996; Sesé et al., 2011). At Arriaga, a TL date of $96+21 /-13$ ka was obtained from the top of the preserved fluvial deposits (Silva et al., 2012b). At Los Estragales, a lacustrine deposit containing over 11,000 lithic pieces, which have provided a TL date of $90.6 \pm 9.1 \mathrm{ka}$, was found within the hiatus recorded between the two alluvial sequences (PérezGonzález et al., 2008).

At Los Estragales, the non-eroded tops of the СТВ have been dated to the MIS 4 with two TL dates of $64.5+15.2 / 11.3 \mathrm{ka}$ and $60.1 \pm 3.4 \mathrm{ka}$ (Pérez-González et al., 2008). The $+12-15 \mathrm{~m}$ is a fill-in terrace over the CTB. Some preserved deposits have been dated to the mid MIS 3 at La Torrecilla and Estanque de Tormentas de Butarque (Domínguez Alonso et al., 2007, 2009; Pérez-González et al., 2008).

\section{CTB sites with proboscidean remains}

Several sand quarries have been established in the fluvial deposits that form the CTB since the middle of the 20th century, boosting the discovery of many lithic and faunal assemblages (Fig. 1C). Only the upper 10 or $12 \mathrm{~m}$ of the total $35 \mathrm{~m}$ that can be reached by the CTB are exploited in these sand quarries. According to the available numerical dates, this would affect the Middle Pleistocene and Early Late Pleistocene (MIS 5-MIS 4) deposits. Table 1 shows the sand quarries of the CTB where remains of proboscideans have been recorded, as well as the quantity of lithic pieces retrieved from each site (Cacho and Martos, 2002; Gamazo, 2002; Sesé and Soto, 2002). The faunal associations found have been biostratigraphically assigned to the Middle and Late Pleistocene. Middle Pleistocene associations feature E. (Paleoloxodon) antiquus, Bos primigenius and Dicerorhinus hemitoechus (Sesé and Soto, 2002b) and Late Pleistocene deposits include Megaceros cf. giganteus, Mammuthus cf. intermedius and Coelodonta antiquitatis (Sesé and Soto, 2002b). In most sand quarries where proboscidean remains have been found, the faunal assemblage has been assigned to the Middle Pleistocene. However, this does not necessarily mean that the whole of the lithic industry found in the sand quarry fits within this period, as worked lithic pieces might come from different stratigraphic levels and could equally belong to the Final Middle Pleistocene or to the Early Late Pleistocene. This would explain the fact that faunal ensembles of the Final Middle Pleistocene and the Early Late have been found together in the same sand quarry. 
Table

Quarry fluvial sands at the CTB with proboscideans remains and quantities of lithic pieces recovered from the sand deposits. Taxa abbreviations: Cai.: Carnivora indet.; Pi.:Proboscidea indet.; cfE(P)a.: cf. Elephas (Palaeoloxodon) antiquus; E(P)a.: Elephas (Palaeoloxodon) antiquus; Mcfi: Mammuthus cf. intermedius; Mcft: Mammuthus trogontherii; Mcfp.: Mammuthus cf. primigenius; Mp.: Mammuthus primigenius; Msp.: Mammuthus sp.; Ei: Elephantidae indet.; Dh.: Dicerorhinus hemitoechus; Ca.: Coelodonta antiquitatis; Ri.: Rhinocerotidae indet.; Ec.: Equus caballus; Ecfh.: Equus cf. hydruntinus; Esp.: Equus sp.; Ssp: Sus sp; Ss: Sus scropha; Csp.: Cervus sp.; Ce.: Cervus elaphus; Dsp: Dama sp.; Mcfg.: Megaceros cf. giganteus; Ci.: Cervidae indet.; cfBp.: cf. Bos primigenius; Bp: Bos primigenius; B/B: Bos/Bison; Bicf.: Bovidae indet. cf.

\begin{tabular}{|c|c|c|c|c|}
\hline Quarry fluvial sands & Taxa & Biochronology & Lithic industry & Source \\
\hline Arenero de Manuel Soto & cfE(P)a.; Ri.; Ec.; Csp.; Dsp.; Bicf.B/B.; Cai. & Middle Pleistocene & Several pieces & $\begin{array}{l}\text { Sesé and Soto, 2002; Gamazo, 1982; Baena Preysler et al., } \\
\text { 2002; Cobo et al., 1979; Gamazo and Cobo, } 1983\end{array}$ \\
\hline Arenero de Los Llanos & E(P)a.; Ec.; Ci.; cfBp. & Middle Pleistocene & 1429 pieces & $\begin{array}{l}\text { Sesé and Soto, 2002; Gamazo, 1982; Priego et al., 1979; } \\
\text { Gamazo, } 2002\end{array}$ \\
\hline Arenero de Santa Elena & E(P)a.; Ri.; Ec.; Ci.; Bicf.B/B. & Middle Pleistocene & 4921 pieces & $\begin{array}{l}\text { Sesé and Soto, 2002; Gamazo, 1982; Santonja and Querol, } \\
\text { 1980; Gamazo, 2002; Cacho and Martos, } 2002\end{array}$ \\
\hline Arenero de Pedro Jaro & E(P)a.; Ri.; Ec.; Ci.; Bicf.B/B. & Middle Pleistocene & 187 pieces & $\begin{array}{l}\text { Sesé and Soto, 2002; Priego et al., 1979; Gamazo, 1982; } \\
\text { Gamazo, } 2002\end{array}$ \\
\hline $\begin{array}{l}\text { Estanque de Tormentas de } \\
\text { Butarque }\end{array}$ & Mp./E(P)a.; Dh.; Ec.; Ecfh.; Ss.; Ce.; Bp; B/B & Later Middle Pleistocene & 2302 pieces & $\begin{array}{l}\text { Álvarez-Lao and García, 2010, 2011; 2012; Ros-Montoya, } \\
\text { 2010; Laplana, personal communication; De los Arcos et al., } \\
\text { 2008, } 2010 .\end{array}$ \\
\hline Arenero de Oxígeno & E(P)a.; Ec.; Ci.; Bicf.B/B. & Middle Pleistocene & 10,416 pieces & $\begin{array}{l}\text { Sesé and Soto, 2002; Gamazo, 1982; Rus and Querol, 1981; } \\
\text { Gamazo, 2002; Cacho and Martos, } 2002\end{array}$ \\
\hline Arenero del Quemadero & E(P)a.; Ec.; Ecfh Bicf.B/B. & Middle Pleistocene & 3809 pieces & Sesé and Soto, 2002; Gamazo, 1982; Gamazo, 2002 \\
\hline Arenero de Jesús Fernández & Pi.; Ce.; Bp. & Uncertain & 1555 pieces & $\begin{array}{l}\text { Sesé and Soto, 2002; Gamazo, 1982; Priego et al., 1979; } \\
\text { Gamazo, } 2002\end{array}$ \\
\hline Arenero de Constantino del Río & Ei.; Ec.; Ssp & Uncertain & 2731 pieces & Sesé and Soto, 2002; Gamazo, 1982; Gamazo, 2002 \\
\hline Arenero de Los Pinos & Ei.; Ri; Ec; Ecfh.; Ce.; Bicf.B/B. & Middle Pleistocene & 5868 pieces & $\begin{array}{l}\text { Sesé and Soto, 2002; Gamazo, 1982; Priego et al., 1979; } \\
\text { Gamazo, 2002; Cacho and Martos, } 2002\end{array}$ \\
\hline Arenero de La Torrecilla & Ei.; Ci. & Uncertain & 1748 pieces & $\begin{array}{l}\text { Sesé and Soto, 2002; Gamazo, 1982; Cobo et al., 1979; } \\
\text { Gamazo and Cobo, 1983; Gamazo, 2002; Cacho and Martos, } \\
2002\end{array}$ \\
\hline Arenero del arroyo Culebro & $\begin{array}{l}\text { E(P)a.; Ei.; Ri; Ec; Ce.; Bi. } \\
\text { Ca.; Mcfg. }\end{array}$ & $\begin{array}{l}\text { Middle Pleistocene } \\
\text { Late Pleistocene }\end{array}$ & 863 pieces & $\begin{array}{l}\text { Soto and Sesé, 1991; Sesé and Soto, 2000; Sesé and Soto, } \\
\text { 2002; Gamazo, 1982; Álvarez-Lao and García, 2011b; Cobo } \\
\text { et al., 1979; Gamazo, } 2002\end{array}$ \\
\hline $\begin{array}{l}\text { Arenero de Los Hijos de Aguado } \\
\text { (o de Ramón Soto) }\end{array}$ & E(P)a.; Msp; Ec. & Middle Pleistocene & 1318 pieces & $\begin{array}{l}\text { Sesé and Soto, 2002; Cobo et al., 1979; Gamazo, 1982; } \\
\text { Gamazo and Cobo, 1983; Gamazo, } 2002\end{array}$ \\
\hline Arenero de Rojas & $\begin{array}{l}\text { E(P)a.; Ec.; Ecfh.; Bicf.B/B. } \\
\text { Mcfi }\end{array}$ & $\begin{array}{l}\text { Middle Pleistocene } \\
\text { Late Pleistocene }\end{array}$ & 3004 pieces & Sesé and Soto, 2002; Gamazo, 1982; Gamazo, 2002 \\
\hline $\begin{array}{l}\text { Arenero de La Fábrica de } \\
\text { Ladrillos }\end{array}$ & $\begin{array}{l}\text { E(P)a.; Dh.; Ec.; Ce.; Bp. } \\
\text { Mcfi }\end{array}$ & $\begin{array}{l}\text { Middle Pleistocene } \\
\text { Late Pleistocene }\end{array}$ & 1074 pieces & Sesé and Soto, 2002; Gamazo, 1982; Gamazo, 2002 \\
\hline Arenero de Arcaraz & $\begin{array}{l}\text { E(P)a. } \\
\text { Mcfi.; Ec.; Mcfg. }\end{array}$ & $\begin{array}{l}\text { Middle Pleistocene } \\
\text { Late Pleistocene }\end{array}$ & 1424 pieces & $\begin{array}{l}\text { Sesé and Soto, 2002; Cobo et al., 1979; Gamazo, 1982; } \\
\text { Gamazo, } 2002\end{array}$ \\
\hline Arenero de Arriaga & $\begin{array}{l}\text { E(P)a.; Msp.; Dh.; Ec.; Ecfh.; Dsp.; Ce; Ci.; Bp } \\
\text { Bicf.B/B. }\end{array}$ & Middle Pleistocene & 3088 pieces & $\begin{array}{l}\text { Soto at Rus, 1989; Sesé and Soto, 2002; Álvarez-Lao and } \\
\text { García, 2012; Rus and Vega Toscano, 1984; Gamazo, 2002; } \\
\text { Cacho and Martos, } 2002\end{array}$ \\
\hline Arenero de casa Eulogio & Ei.; Mcft.; Esp.; Ci.; Bp.; Mcfp.; Ec.; Ce. & Middle Pleistocene & 228 pieces & $\begin{array}{l}\text { Sesé and Soto, 2002; Álvarez-Lao and García, 2010, 2012; } \\
\text { Gamazo, 1982; Cobo et al., 1979; Gamazo, 2002; Cacho and } \\
\text { Martos, 2002 }\end{array}$ \\
\hline
\end{tabular}




\section{6. СTB proboscidean remains with human intervention}

The four sites with remains of proboscideans found in the CTB are located along $4 \mathrm{~km}$ of the final reach of the Manzanares Valley (Fig. 1C). Along this reach, which runs between the confluence with the Arroyo Culebro stream and its mouth at the River Jarama, the river deepens to about $100 \mathrm{~m}$ within the gypsum bedrock and forms a $2.5-1.5 \mathrm{~km}$ wide valley. The River Jarama and the PradosGuatén Depression which connects with Arroyo Culebro, where remains of these mega-herbivores have also been found (Santonja et al., 1980), are also fluvial nets belonging to the right bank of one of the main rivers of the Iberian Peninsula, the River Tagus (Fig. 1B). This forms the final reach of the Manzanares Valley, a crossroads that could have been considered a special case of the concentrate resources model (Haggett et al., 1977; Butzer, 1982).

\subsection{Arriaga IIa}

The site is located to the top of the CTB, within a level of fine sand overlying marls and muds (Silva et al., 2012b, Fig. 4), which have been interpreted as the established surface of an old floodplain (Rus and Vega Toscano, 1984). It has been dated to the end of the Middle Pleistocene, judging by the available numerical dates (see above) (Silva et al., 2012b) and the evolved stage of Microtus brecciensis and Arvicola aff. sapidus (Sesé and López Martínez, i.p.). These remains and dates were obtained from secure stratigraphic contexts, directly overlying and underlying the site.

The excavation covered an area of $56 \mathrm{~m}^{2}$ (Fig. 3A) where 43 lithic pieces associated with the remains of an adult female individual of E. (Paleoloxodon) antiquus were recorded from within a sandy layer. All the remains discovered were grouped in a 7-8 $\mathrm{m}^{2}$ area. The skull was upside-down; both tusks were preserved (Fig. 3B), as well as the lower jaw with M3, upper molars, right scapula, vertebrae and ribs (Rus and Vega Toscano, 1984; Santonja et al., 2001). Taphonomic study of the bone remains (which has been carried out by the author J.Y.) revealed just one contentious mark found on a proboscidean rib. This mark appears to have a V-section, but there are doubts about its nature due to its slightly wide and irregular shape, its small size, and its isolated position, which suggests that it could have been the result of trampling.

Semicircular features recorded at this site, with diameters below $17-22 \mathrm{~cm}$, have been interpreted as elephant footprints (Silva et al., 2012b). A circular pit $25 \mathrm{~cm}$ in diameter and $50 \mathrm{~cm}$ in depth was located below the elephant remains, and this was interpreted as a human-made structure (Rus and Enamorado, 1991; Santonja et al., 2001), although more recently it has been suggested that it may be a hole made by elephants while trying to get water from the dry riverbed (Rus and Santonja, 2011).

A total of 43 lithic pieces surrounded the elephant remains. Their distribution suggests a possible activity surface of some $35 \mathrm{~m}^{2}$. The lithic industry, composed of cores, bifaces, scrapers and flakes, was worked from local flint nodules, and is characterised by its low degree of elaboration, small amount of retouched pieces, and scarce levallois products (Rus and Vega Toscano, 1984). Most pieces were between $7 \mathrm{~cm}$ and $10 \mathrm{~cm}$ long (bifaces, scrapers, choppers and flint cores). They showed sharp edges and were extracted from the same nodule, which suggests that they were associated with the elephant (Rus and Enamorado, 1991). Smaller flint pieces displaying slight fluvial rolling, the same size as pebbles moved by the River Manzanares $(3-4 \mathrm{~cm})$, have been interpreted as being deposited by a stream that would have simultaneously moved pieces smaller than $3 \mathrm{~cm}$. However no such small pieces were found (Rus and Vega Toscano, 1984). The 43 pieces- assemblage has not been the subject of a detailed publication. As regards to the available information, their association with the Acheulean industry cannot be ruled out, although they have been associated with the Upper Acheulean (Rus and Vega Toscano, 1984: 396) and it has been pointed out that they show the same characteristics as the assemblage of $\sim 1000$ pieces found in a sand level overlying Arriaga IIa, which was identified with an Early Middle Palaeolithic phase (Vega Toscano et al., 1999; Silva et al., 2012b).

The association of micromammals found at Arriaga: Crocidura sp., Talpa sp., Eliomys quercinus, Apodemus sp., M. brecciensis, Microtus arvalis, Microtus duodecimcostatus, Arvicola aff. Sapidus, and Oryctolagus cuniculus, suggests temperate weather conditions and an open landscape (80\%), where very wet and wet meadows with plenty of bush vegetation would have predominated. Some less wet areas with bush vegetation would equally be important, and there would also be a substantial amount of forests (20\%). All these characteristics: numerous wet areas and good development of vegetation, whether herbaceous, bush or forest, point not only to the wetness requirements linked to the proximity of a river, but also the presence of a moist environment which would favour it (Sesé and López Martínez, 2013).

\subsection{Arenero de Rojas Finca de la Aldehuela}

One skull with both tusks of E. (Paleoloxodon) antiquus were found in a sandy level, $4 \mathrm{~m}$ below the top of the CTB, which allows it to be chronologically located between MIS 6 and MIS 5, as well as 29 worked lithic pieces (S. Quero, personal communication), probably associated with elephant processing. The cortical surface of the elephant skull, which was studied by one of the authors (J. Y.), is too badly preserved to allow the identification of any anthropogenic marks.

The lithic assemblage found with the elephant, which has also been studied by two of the authors (S. R-J. and J. P.), is composed of 29 flint pieces, three cores, one chunk and 25 flakes. The edges of five of those flakes, measuring between 23 and $36 \mathrm{~mm}$ length, have been altered due to fluvial rolling, whereas the remaining flakes show sharp or slightly altered edges, suggesting that they could be related to the proboscidean.

The largest of the three cores found $(103 \times 75 \times 39 \mathrm{~mm})$ is of recurrent centripetal Levallois type (Böeda, 1993). It is not too exhausted and shows eight negative scars per surface. The other two cores are of medium size and are exploited to exhaustion. The flakes are of medium size $(45 \times 39 \times 13 \mathrm{~mm}$ in average $)$. One Levallois flake $(71 \times 58 \times 13 \mathrm{~mm})$, one Levallois point $(43 \times 30 \times 5 \mathrm{~mm})$, and two resharpening flakes, one from a tool and another one possibly from a biface $(34 \times 43 \times 12 \mathrm{~mm})$, are remarkable. There are 13 retouched flakes which are larger than the whole flake assemblage $(52 \times 44 \times 13 \mathrm{~mm})$. Four scrapers and one awl show a well-shaped retouch, whereas the remaining flakes show a less powerful retouch: these are four retouched flakes, two single-blow notches and one complex notch, as well as a tool fragment. The assemblage stands out due to the presence of Levallois elements (including one point), the high percentage of retouched tools and the presence of resharpening (a biface and a retouched tool), which is consistent with having been used and abandoned on site.

\subsection{EDAR Culebro 1}

This site was identified in a $40 \mathrm{~cm}$ thick sandy level, $2 \mathrm{~m}$ below the top of the CTB, which has been eroded in this sector by the Arroyo Culebro stream. The date of $120.541 \pm 6.851$ ka obtained by OSL (Manzano et al., 2010) would assign the site to the Eemian. The chronological frame, however, has been extended due to the range obtained via Amino-Acid Racemization (AAR) techniques on Equus 
sp. molar, $133 \pm 28$ and $105 \pm 10 \mathrm{ka}$, which place this site between MIS 6 and MIS 5c (Silva et al., 2012b).

Some $150 \mathrm{~m}^{2}$ were excavated. Remains of a sub-adult male Mammuthus cf. intermedius (Manzano et al., 2010) or M. primigenius (Álvarez-Lao and García, 2011b) were found in $60 \mathrm{~m}^{2}$ (Fig. 4A). The identified remains consisted of a lower jaw, six ribs, one fragment of the right humerus and one of left humerus, several fragments of diaphysis and of tusks (Fig. 4B). Green-bone fracture patterns have been identified on these bones, indicating that this process was human-made (Yravedra at Manzano et al., 2010). Several lithic pieces and remains of Equus sp. and Cervidae were also found in this level.

The lithic assemblage, which was made of local flint, consisted of two discoidal cores, one bifacial and one polyhedric; flakes, some of which may have been the product of resharpening; and a number of tools and knapping remains. Macro-tools and percussion elements were not recorded. The absence of highly rolled pieces suggest that the lithic assemblage, despite having been found in a level of sand, did not undergo much transportation (Manzano et al., 2010).

As micromammal remains were not recorded, climatic data has been inferred from the pollen association recorded in the same level where the remains of mammoth were found. These reveal a temperate, dry Mediterranean climate, and a landscape featuring a scarce forest surface composed of Olea and Ulmus, with Juniperus and Rosacea defining the bush stratum, and with dominant herbaceous plants such as Chenopodiaceae, Poaceae, Solanaceae, Plantago and Rumex. There were no aquatic elements in the sample (Manzano et al., 2010).

\subsection{PRERESA}

This site is located between two fluvial sequences, $5.5 \mathrm{~m}$ below the top of the CTB, deposited during the second half of MIS 5, according to the numerical date of $84.126 \pm 5.633$ ka obtained by OSL in feldspar grains. The evolved stage of Microtus cabrerae and Arvicola aff. sapidus suggests an Early Late Pleistocene association, which is consistent with the numerical date (Sesé et al., 2011).
An area of $255 \mathrm{~m}^{2}$ was excavated. There were recorded 754 lithic pieces, as well as an important association of micromammals and the remains of Vulpes vulpes, Lynx pardinus, Meles meles, Canis lupus, Proboscidea indet., Equus sp., Cervus elaphus, Dama sp., Capreolus capreolus, and Bos primigenius. 82 bones of proboscidean, belonging to one individual, were also recovered. These included carpals, tarsals, phalanges, fragments of tusk, metapodials, vertebrae, ribs, one complete scapula, one partial ulna, and several fragments of long diaphysis and tibiae (Fig. 5B).

Taphonomic analysis shows that preservation conditions of the fauna was excellent. The exploitation of proboscideans has been observed through the identification of cut marks on six diaphysis fragments. Additionally, the intentional breaking of bones is suggested by the presence of percussion marks and green-bone fractures found on other bone fragments, confirming that the bone marrow of these taxa was also consumed (Yravedra et al., 2012).

The lithic assemblage consists of 754 pieces, all worked from flint apart from six pieces of quartz, showing very sharp edges. The flint chaînes operatoires are complete. Cores were exhaustively exploited. Short operative chains prevail, as well as flakes greater in width than in length. The lack of macro-tools and the low occurrence of retouched tools is remarkable. Among these, the most common are retouched flakes, denticulates and compound tools. A scraper and a burin were also recorded. The presence of knapping remains and refits demonstrate that these flakes were shaped in situ (Rubio-Jara, 2011) and probably used, judging by the presence of cut marks on the bones. The scattering and arrangement of the faunal remains, together with the characteristics and distribution of the lithic industry, as well as the cut and percussion marks on the elephant bones recovered from the site, suggest that parts of these animals were subject to processing by humans.

The elephant remains were scattered over a $130 \mathrm{~m}^{2}$ surface, although the highest concentration of industry and faunal remains was found in a $36 \mathrm{~m}^{2}$ area (Fig. 5A). Only 182 lithic pieces are longer than $3 \mathrm{~cm}$, and only 75 of those are longer than $5 \mathrm{~cm}$.

The herpetological assemblage recovered in PRERESA, consisting of Pelobates cultripes, Pelodytes sp., Bufo bufo, Bufo calamita, Hyla

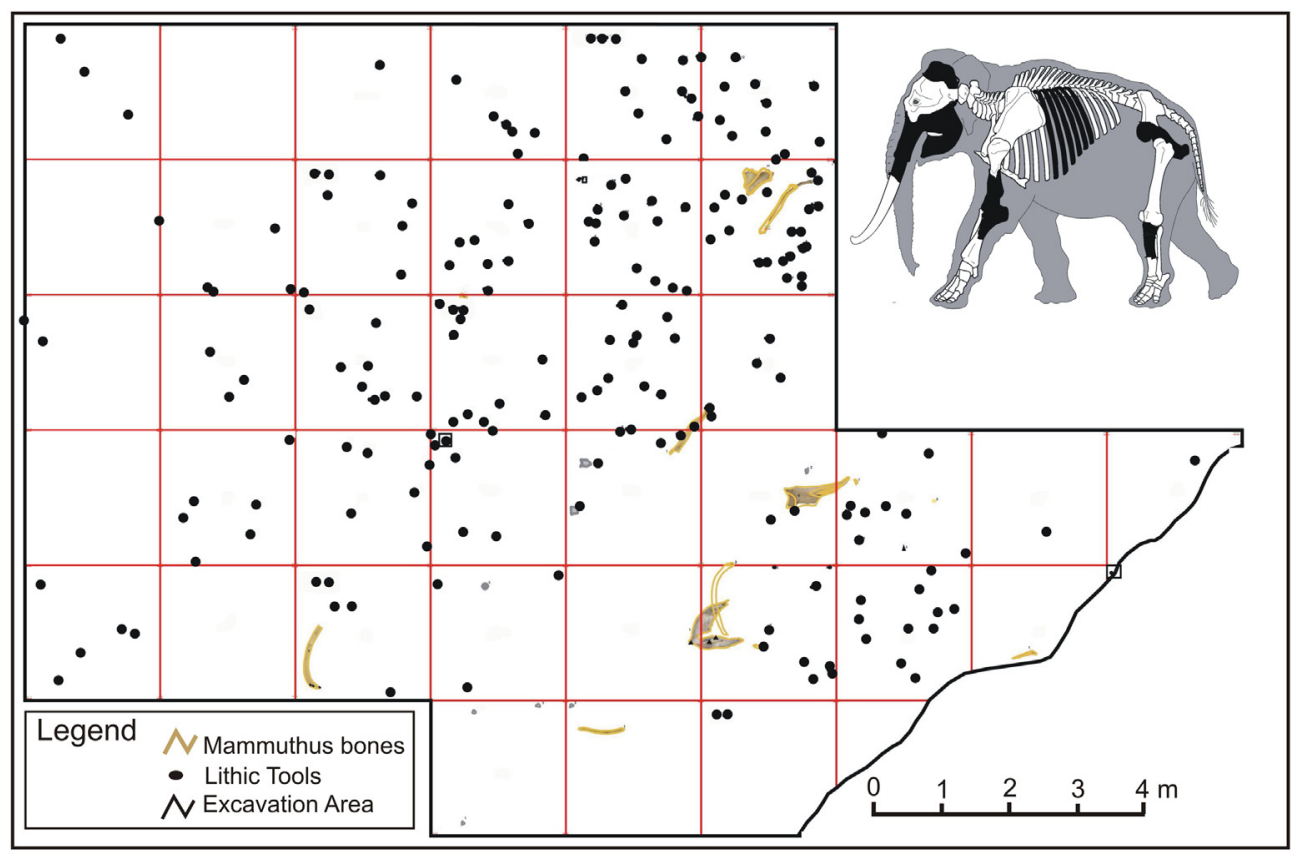

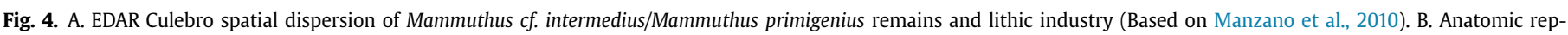
resentation of the mammoth remains found at EDAR Culebro. 


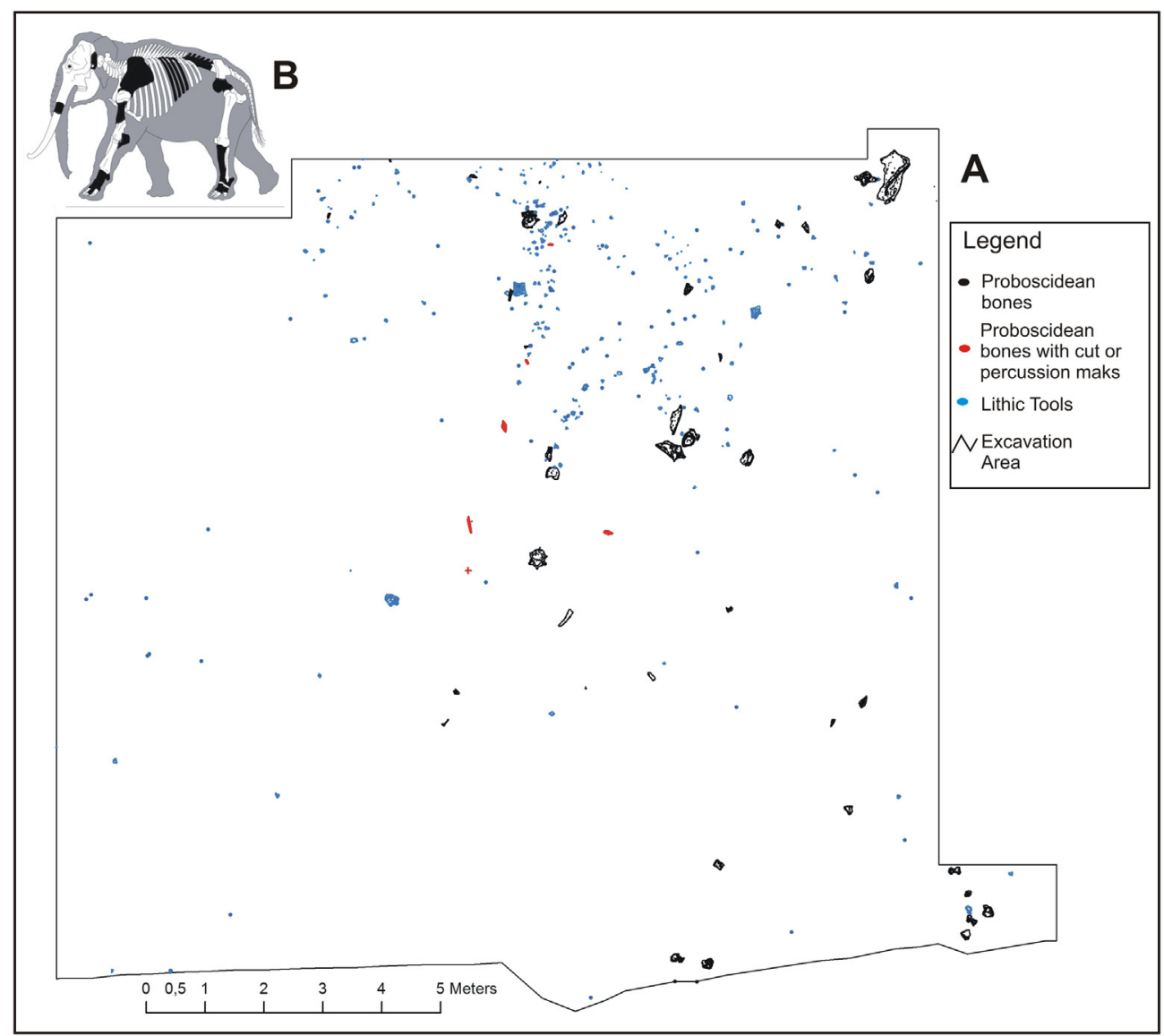

Fig. 5. A. PRERESA spatial dispersion of proboscidean remains and lithic industry. B. Anatomic representation of the proboscidean remains found at PRERESA.

sp. and Pelophylax perezi, Testudinoidea indet., Blanus sp., Timon lepidus, Psammodromus cf. algirus, Natri maura, Coronella sp. and Vipera latastei, reveals a climate of Mediterranean type, with four months of aridity during the summer and beginning of fall, identical to or even warmer than the current one, with more abundant rainfalls during winter and spring; and a lesser continentality, linked with a certain increase of winter temperatures (Blain et al., 2013). The micromammal assemblage, consisting of Erinaceus europaeus, Crocidura russula, Rhinolophus ferrumequinum, Eliomys quercinus quercinus, Apodemus sp., Cricetulus (Allocricetus) bursae, Arvicola aff. sapidus, M. cabrerae, M. duodecimcostatus and O. cuniculus, suggests that forest areas would have been poorly represented (8.3\%), and the landscape would have been mainly open, with some areas of forest edge and meadow (1.2\%) with wetlands and riverbank vegetation (56.8\%). The remaining landscape would have been composed of wet and dry meadows (29\%), dry meadows (1.8\%) and dry meadows or steppes (2.4\%). Therefore, the landscape could well have consisted of woodland or riverbank forest, with plenty of riverbank vegetation and wetlands, which would change to more open areas with bush vegetation and wet meadows, and finally dry meadows and steppes in the furthest areas from the riverbanks (Sesé et al., 2011).

\section{Discussion}

Evidence from stable isotope studies of Neanderthal remains indicate that in several regions of Europe, between 120 and $37 \mathrm{ka}$, Neanderthals were top-level carnivores, receiving most of their protein from large mammals (Richards and Trinkaus, 2009), and even at times from extremely large mammals such as rhinoceros and mammoths (Bocherens et al., 2005; Bocherens, 2011). Several of these zooarchaeological studies confirm that the systematic exploitation of large mammals during the Middle Palaeolithic occurred, and it is accepted that they were regularly hunted (Gaudzinski, 1996; Gaudzinski and Roebroeks, 2000). However, in contrast to Lower Palaeolithic records, the exploitation of proboscideans is not as obvious in the Middle Palaeolithic (Gaudzinski and Kindler, 2012).

The clearest evidence of Neanderthals exploiting proboscideans is limited to the sites of La Cotte de St Brelade, Bolomor, Byzovaya, Spy, Saint-Césaire, and Salzgitter-Lebenstedt. Bone remains with definite cut marks were found at the first three sites, as well as at Molodova I and Kulna, although the evidence from these last two sites is not as clear. At Spy and Saint-Césaire, stable isotope analysis on Neanderthal remains has indicated the consumption of mammoths. Bones of this animal were used as raw material in SalzgitterLebenstedt and possibly at Molodova I. Nine flakes with use-wear traces, associated with a carcass of Elephas (Palaeoloxodon) antiquus, found in Gröbern, are also solid proof of elephant consumption. Such solid evidence has not been found in Pagnano d'Asolo, Lehringen nor in Ariendorf 2, however, enough indications have been recorded for them to be included within the group mentioned above. Cava Campitello, Santo Antao do Tojal (Zbyszewski, 1943), and Lynford present more problems: no detailed publication is available for the first two sites, and the last is actually a palimpsest and so it is not clear whether humans did indeed exploit mammoths or just other mammals.

European sites which show evidence of proboscidean exploitation are substantially greater in number during the Lower Palaeolithic. Cut marks were identified in Aridos 2, Spain (Yravedra et al., 
2010), Isernia La Pineta, Italy (Mussi, 2005), Castel di Guido, Italy (Radmilli and Boschian, 1996; Anconetani and Boschian, 1998; Saccà, 2012), and Bilzingsleben, Germany (Mania, 1990). They were also possibly identified at Ambrona, Spain (Villa et al., 2005) and Notarchirico, Italy (Mussi, 2005). With regards to the Middle East, cut marks were identified at Gesher Benot Ya'Akov, Israel (Goren-Inbar et al., 1994), and Revadim, Israel (Rabinovich et al., 2012). There are also a number of sites where proboscidean bones have been used as a raw material: Castel di Guido, Italy (Radmilli and Boschian, 1996; Villa et al., 2005; Saccà, 2012), La Polledrara, Italy (Villa et al., 1999; Anzidei et al., 2004; Anzidei et al., 2012), Fontana Ranuccio, Italy (Segre and Ascenzi, 1984), Malagrotta, Italy (Cassoli et al., 1982), Casal de Pazzi, Italy (Anzidei and Ruffo, 1985; Anzidei et al., 1999), Verteszölös, Hungary (Dobosi, 2001), Bilzingsleven, Germany (Mania and Weber, 1986) and Revadim, Israel (Rabinovich et al., 2012). In Áridos 1 and Áridos 2, Spain (Santonja et al., 1980; Ollé, 2005), as well as in La Polledrara, Italy (Anzidei et al., 2012) use-wear traces from meat and/or skin extraction have been associated with elephant remains. Finally, lithic industry and faunal remains found together have been described since the oldest European archaeological record in Fuente Nueva III (Patrocinio et al., 2013), as well as the beginning of the Middle Pleistocene in La Boella, Spain (Saladié et al., 2008; Vallverdú et al., 2009), and to the middle of the Middle Pleistocene in TRANSFESA, Spain (Meléndez and Aguirre, 1958; Andrés and Aguirre, 1974), TAFESA, Spain (Baena Preysler and Baquedano, 2004; Baena Preysler et al., 2010), Torralba, Spain (Howell, 1966; Freeman, 1994; Santonja and Pérez-González, 2005), KärlichSeeufer, Germany (Kröger et al., 1991; Gaudzinski, 1996), San Isidro, Spain (Santonja et al., 2001) and Stanton Harcourt, England (Scott, 2001).

Despite sites with proboscidean exploitation occurring more frequently during the Lower Palaeolithic, there is a scarcity of sites with evidence of hunting of these mega- herbivorous belonging to the Middle Palaeolithic. These are La Cotte de St Brelade, Spy and Molodova I, and also probably at Pagnano d'Asolo and Lehringen. The ability of Neanderthals to capture these pachyderms does not seem to be consistent with the decrease in the archaeological record of sites with evidence of elephant exploitation, especially keeping in mind the fact that they provide a substantial amount of meat and fat. Animal protein was an essential part on the diet of these hominins (Richards and Trinkaus, 2009), and the inclusion of large amounts of animal protein requires greater ingestion of fat and/or carbohydrate to prevent protein toxicity (Speth, 1991; Cordain et al., 2000). Moreover, proboscideans are easy to find due to their clearly identifiable travel routes, the way in which they modify the landscape and the implicit information given by their excrement (McNeil et al., 2005; Haynes, 2006, 2012; Shannon et al., 2009). Finally, they offer human groups a series of advantages with which to exploit the ecosystems that they frequent (Haynes, 2001, 2006).

Management of resources could explain, at least in part, the lower number of Middle Palaeolithic sites showing proboscidean exploitation. During this period most of the archaeological record is located within caves and rock shelters, places where remains of mega-herbivores have seldom been found. This could be explained by the fact that large boneless pieces of elephant meat could have been transported, as it has been stated in St. Cesaire and Spy. Without the stable isotope studies from these sites it would have been impossible to infer from the archaeological record that mammoth was an important part in the diet of the Neanderthals who lived in these sites.

According to the information provided by the micromammals, the landscape of the CTB at the time of Arriaga and PRERESA would have been mainly open, with a predominance of wet meadows with herbaceous or bush vegetation, and drier areas with bush, and also some forest. This type of vegetation would have required not only wet conditions linked to the proximity of a river, but also wet environmental conditions (Sesé and López Martínez, i.p.; Sesé et al., 2011). Therefore, the CTB would have provided the Neanderthals with a mixed habitat, mainly open and partially forested, where plant foods could have played an important role in their diet, as is suggested by the occlusal molar microwear analysis of 19 adult Neanderthals from western Eurasian sites (El Zaatari et al., 2011). Although these hominins had a predominantly carnivorous diet, plant resources played a more important role in mixed forest areas than in open-steppe areas.

The microvertebrates and pollen from Arriaga, EDAR Culebro and PRERESA reveal a temperate climate of Mediterranean type. The herpetological assemblage from PRERESA suggests four months of aridity during the summer and the beginning of fall. This is an identical, indeed warmer, climate than the current one, with more abundant rainfalls during winter and spring, and a lesser continentality, linked with a certain increase of winter temperatures (Blain et al., 2013). Moreover, the CTB and the lower course of the River Jarama run through a gypsum saline substrate, limiting the development of plant species. Thus, the summer drought period would favour the use of these valleys as ecological corridors. Therefore, it seems probable that macromammals, including proboscideans, concentrated along the riverbanks, as can be currently observed at the East African reserve parks. Due to the lack of accumulation of several individuals at the same site in the fossil record, it is not possible to consider extreme drought periods, as can be seen in the present day where elephant carcasses are accumulated in the same place (Haynes, 1991). However, the concentration of fauna during dry months would greatly facilitate hunting and scavenging.

The discovery of four sites with evidence of proboscidean exploitation occurring between MIS 6 and MIS 5 in the CTB, suggests that there was no substantial change of subsistence strategies between the Lower and Middle Palaeolithic with regard to these mammals, at least at the Manzanares Valley. Here, there is a significant amount of Acheulean sites showing lithic industry together with elephant remains: San Isidro, TRANSFESA, TAFESA, and other sites very nearby in the Jarama Valley such as Áridos 1 and Áridos 2. Additionally, climatic and landscape data inferred from the micromammals and macromammals found reveal that to the end of the Middle Pleistocene and early Late Pleistocene the available plant and animal resources would have been similar to those available during the Acheulean. The combination of resource management, climate and ecosystem could explain the large number of proboscidean carcasses found together with lithic industry dating to the Middle Palaeolithic found at the CTB.

\section{Conclusions}

Proboscideans have been considered a 'keystone' species (Owen-Smith, 1999; Robinson et al., 2003). The ecosystems that they frequented could have facilitated the exploitation of resources for human groups during the Pleistocene (Haynes, 2006). Additionally, proboscideans provide a substantial amount of meat and fat, and hunting these animals does not necessarily require sophisticated technology (Ben-Dor et al., 2011).

It has been discussed whether the association of proboscidean remains and lithic tools before the Upper Palaeolithic is meaningful or simply a bias produced by their better preservation due to the size of the remains (Haynes, 1991; Gaudzinski et al., 2005; Villa et al., 2005). However, recent publication of new data points out that exploitation of proboscideans cannot be considered an unusual activity before the Upper Palaeolithic, and that there is more 
evidence of exploitation during the Lower than the Middle Palaeolithic (Mussi and Villa, 2008; Yravedra et al., 2010, 2012; Slimak et al., 2011; Ben-Dor et al., 2011; Germonpré et al., 2012; Rabinovich et al., 2012; Saccà, 2012; Smith, 2012).

A large number of proboscidean remains dating to the final Middle Pleistocene and early Late Pleistocene have been recorded in the CTB of the Manzanares Valley (Sesé and Soto, 2002). The geographical location of this area, the Mediterranean climate characteristics identified during this period (Sesé et al., 2011; Blain et al., 2013) as well as its surrounding ecosystems, could have favoured the presence of large mammals along the riverbanks of the final reach of the river, especially during the summer drought period, establishing a special case of the concentrate resources model (Haggett et al., 1977; Butzer, 1982).

Many Acheulean sites containing lithic industry together with elephant remains have been found in the Manzanares Valley (Meléndez and Aguirre, 1958; Santonja et al., 1980; Baena Preysler et al., 2010). To the end of the Middle Pleistocene and the beginning of the Late Pleistocene, the remains of proboscideans associated with lithic industry found in the CTB (in some cases with cut and percussion marks and green-bone fractures) (Rus and Vega Toscano, 1984; Manzano et al., 2010; Yravedra et al., 2012) show that these mega-herbivores were constantly exploited as a resource during the Middle Palaeolithic. This does not seem to have any relation to changes in the availability of animal or plant resources, which would propitiate a greater interest on proboscideans, but with the advantages which they offered to groups of huntersgatherers.

\section{Acknowledgments}

We wish to express our gratitude to Krzysztof Cyrek and Adam Nadachowski for inviting us to participate in this special issue; to Norm Catto and two anonymous reviewers for their suggestions, which have greatly improved the final text; to the Museo de San Isidro (Madrid) and to Mercedes Gamazo for her assistance on the supervision of the remains of Arenero de Rojas; to Salvador Quero for the information provided about the site Arenero de Rojas; to the Dirección General de Patrimonio Histórico de la Comunidad de Madrid for financing the excavation works at PRERESA; to Iván González, Nuria Gallego, Primitivo Javier Sanabria and Miguel Díaz for supervising the excavation works at the PRERESA site; and to Marta Muñiz and Ciara Travers for text translation and English corrections.

\section{References}

Adam, K.D., 1951. Der Waldelefant von Lehringen, eine Jagdbeute des dilluvialen Menschen. Quartär 5, 79-92.

Álvarez-Lao, D.J., García, N., 2010. Chronological distribution of Pleistocene coldadapted large mammal faunas in the Iberian Peninsula. Quaternary International 212, 120-128.

Álvarez-Lao, D.J., García, N., 2011a. Geographical distribution of Pleistocene coldadapted large mammal faunas in the Iberian Peninsula. Quaternary International 233, 159-170.

Álvarez-Lao, D.J., García, N., 2011b. Southern dispersal and Palaeoecological implications of woolly (Coelodonta antiquitatis): review of the Iberian occurrences. Quaternary Science Reviews 30, 2002-2017.

Álvarez-Lao, D.J., García, N., 2012. Comparative revision of the Iberian woolly mammoth (Mammuthus primigenius) record into a European context. Quaternary Science Reviews 32, 64-74.

Anconetani, P., Boschian, G., 1998. A case study from Castel di Guido (Roma e Italy): Elephas namadicus. In: Brugal, J.P., Meignen, L., Patou-Mathis, M. (Eds.), Économie préhistorique: les comportements de subsistance en Paléolithique. Actes XIII Rencontres Internationales d'Archéologie et d'Histoire de Antibes, Antibes, 25-27 October 1997, Apdca, Sophia-Antipolis, pp. 121-131.

Andrés, I., Aguirre, E., 1974. Un molde endocraneano de Praedama (cérvido) del Pleistoceno Medio de Madrid. Quaternaria 18, 303-330.

Anzidei, A.P., Arnoldus-Huyzenveld, A., Caloi, L., Lemorini, C., Palombo, M.R., 1999. Two Middle Pleistocene sites near Rome (Italy): La Polledrara di Cecanibbio and
Rebibbia-Casal de’ Pazzi. In: Gaudzinski, S., Turner, E. (Eds.), The Role of Early Humans in the Accumulation of European Lower and Middle Palaeolithic Bone Assemblages, Mainz, Monographien des Romisch Germanischen Zentralmuseum, vol. 42, pp. 173-195.

Anzidei, A.P., Arnoldus-Huizendveld, A., Palombo, M.R., Argenti, P., Caloi, L., Marcolini, F., Lemorini, L., Mussi, M., 2004. Nouvelles données sur le gisement Pléistocène moyen de La Polledrara di Cecanibbio (Latium, Italie). In: Baquedano, E., Rubio-Jara, S. (Eds.), Miscelànea en homenaje a Emiliano Aguirre, Zona Archeologica, vol. 4. Archeologia. Museo Arqueológico Regional, Madrid, pp. 20-29.

Anzidei, A.P., Bulgarelli, G.M., Catalano, P., Cerilli, E., Galloti, R., Lemorini, C., Milli, S. Palombo, M.R., Pantano, W., Santucci, E., 2012. Ongoing research at the late Middle Pleistocene site of La Polledrara di Cecanibbio (central Italy), with emphasis on human-elephant relationships. Quaternary International 255, $171-187$.

Anzidei, A.P., Ruffo, M., 1985. The Pleistocene deposit of Rebibbia-Casal de' Pazzi (Rome, Italy). In: Papers in Italian Achaeology IV- Part I. The Human Landscape. British Archaeological Research International Series, vol. 243, pp. 69-85.

Arche, A., 1983. Coarse-grained meander lobe deposits in the Jarama River, Madrid. Spain. In: Collinson, J.D., Lewin, J. (Eds.), Meander and Ancient Fluvial Systems. International Association Sedimentology, pp. 313-321 (Special Publication 6).

Baena Preysler, J., Baquedano, I., 2004. Avance de los trabajos arqueológicos realizados en el yacimiento paleolítico de Tafesa, antiguo Transfesa (Villaverde, Madrid): principales rasgos tecnológicos del conjunto lítico. In: Baquedano, E. Rubio-Jara, S. (Eds.), Miscelánea en homenaje a Emiliano Aguirre, IV, Zona Arqueológica, vol. 4, pp. 31-47.

Baena Preysler, J., Baquedano, I., Carrión, E., 2010. La industria lítica del yacimiento paleolítico de TAFESA (Madrid). In: Baena, J., Baquedano, I. (Eds.), Las huellas de nuestro pasado. Estudio del yacimiento del Pleistoceno Madrileño de Tafesa (Antigua Transfesa), Zona Arqueológica, vol. 14, pp. 37-134.

Baena Preysler, J., Conde Ruiz, C., Gamazo, M., Sesé, C., Soto, E., 2002. Repertorio de yacimientos paleolíticos del Manzanares y del Jarama. In: Panera, J., RubioJara, S. (Eds.), Bifaces y elefantes. La investigación del Paleolítico Inferior en Madrid, Zona Arqueológica, vol. 1, pp. 461-491.

Bahuchet, S., 1987. Historical perspectives on the Aka and Baka pygmies in the Western Congo basin. In: 66th Congress of the American Anthropological Association, Session "Pygmies of the Western Congo Basin".

Ben-Dor, M., Gopher, A., Hershkovitz, I., Barkai, R., 2011. Man the fat hunter: the Demise of Homo erectus and the emergence of a new hominin lineage in the Middle Pleistocene (ca. 400 kyr) levant. PLoS One 6 (12), e28689. http:/ dx.doi.org/10.1371/journal.pone.0028689.

Benito, G., Gutiérrez, F., Pérez-González, A., Machado, M.J., 2000. Geomorphological and sedimentological features in Quaternary fluvial systems affected by solution-induced subsidence (Ebro Basin, Spain). Geomorphology 33, 209-224.

Benito, G., Pérez-González, A., Gutiérrez, F., Machado, M.J., 1998. River response to Quaternary subsidence due to evaporite solution (Gállego river Ebro basin, Spain). Geomorphology 22 (3-4), 243-263.

Binford, L.R., 1983. In Pursuit of the Past. Decoding the Archaeological Record Thames and Hudson, London.

Blain, H.-A., Sesé, C., Rubio-Jara, S., Panera, J., Uribelarrea, D., Pérez-González, A., 2013. Reconstruction paléoenvironnementale et paléoclimatique du Pléistocène supérieur ancien (MIS 5a) dans le Centre de l'Espagne: les petits vertébrés (Amphibia, Reptilia \& Mammalia) des gisements de HAT et PRERESA (Sud-est de Madrid). Quaternaire 24 (2), 191-205.

Blasco, R., Fernández Peris, J., 2012. A uniquely broad spectrum diet during the Middle Pleistocene at Bolomor Cave (Valencia, Spain). Quaternary International 252, 16-31.

Bocherens, H., 2011. Diet and ecology of Neanderthals: implications from C and N isotopes. Insights from bone and tooth biogechemistry. In: Conard, N.J., Richter, J. (Eds.), Neanderthal Lifeways, Subsistence and Technology: One Hundred Fifty Years of Neanderthal Study, Vertebrate Paleobiology and Paleoanthropology, pp. 73-85.

Bocherens, H., Ducker, D.G., Biliou, D., Patou-Mathis, M., Vandermeersch, B., 2005 Isotopic evidence for the diet and subsistence pattern of the Saint-Césaire Neanderthal: review and use of a multi-source mixing model. Journal of Human Evolution 49, 71-87.

Böeda, E., 1993. Le débitage discoïde et le débitage Levallois récurrent centripète. Bulletin de la Société Préhistorique Française 90 (6), 392-404.

Brothwell, D., Schrve, D.C., 2012. Pathologies in the Lynford mammoth assemblage. In: Boismier, W.A., Gamble, C., Coward, F. (Eds.), Neanderthals Among Mammoths. Excavations at Lynford Quarry, Norfolk. English Heritage, pp. 191-202.

Butzer, K.W., 1982. Archaeology as Human Ecology: Method and Theory for a Contextual Approach. Cambridge University Press.

Cacho, C., Martos, J.A., 2002. Colecciones paleolíticas de Madrid en el Museo Arqueológico Nacional. In: Panera, J., Rubio-Jara, S. (Eds.), Bifaces y elefantes. La investigación del Paleolítico Inferior en Madrid, Zona Arqueológica, vol. 1, pp. 382-407.

Carrillo, L., Gisbert, J., Arche, A., 1978. Modelo de sedimentación de la terraza baja (+18-20) del río Manzanares. Estudios Geológicos 34, 549-552.

Cassoli, P.F., De Giulii, C., Radmilli, A.M., Segre, A.G., 1982. Giacimento del Paleolitico inferiore a Malagrotta (Roma). In: Atti della XXIII Riunione Scientifica Istituto Italiano di Preistoria e Protostria. Firenze, pp. 531-549.

Chernysh, A.P. 1982. Paleolithic multilayered Molodova I site. In: Goretsky, G.I. Ivanova, I.K. (Eds.), Molodova I: Unique Mousterian Settlement on the Middle Dniestr Region. Nauka, Moscow, pp. 6-102 (in Russian). 
Chernysh, A.P., 1989. O mustyerskikh zhilishchakh i poseleniyakh. In: Bibikov (Ed.) Kamennyvek Pamyatniki, Metodika, Problemy. Naukova dumka, Kiev, pp. 72 81 (in Russian).

Cobo, A., Gamazo, M., Hoyos, M., Soto, E., 1979. Los yacimientos Paleolíticos de las terrazas del Manzanares. In: Estado actual de la cuestión. I Jornadas de Estudios sobre la Provincia de Madrid (Madrid 1979), pp. 38-43.

Cordain, L., Brand Miller, J., Eaton, S.B., Mann, N., Holt, S.H.A., Speth, J.D., 2000 Plant-animal subsistence ratios and macronutrient energy estimations in worldwide hunter-gatherers diet. American Journal of Clinical Nutrition 71, 682-692.

Crader, D.C., 1983. Recent single-carcass bone scatters and the problem of "butchery" sites in the archaeological record. In: Clutton-Brock, J., Grigson, C. (Eds.) Animals and Archaeology: Hunters and Their Prey, British Archaeologica Research International Series, vol. 163, pp. 107-141.

Demay, L., Péan, S., Patou-Mathis, M., 2012. Mammoths used as food and building resources by Neanderthals: zooarchaeological study applied to layer 4, Molodova I (Ukraine). Quaternary International 276-277, 212-226.

De los Arcos, S., Gallego, N., Gil Ortiz, C., González García, I., Yravedra, J., 2008. Geoarqueología del yacimiento paleolítico del Estanque de Tormentas de Butarque (Villaverde, Madrid). OrJIA (Coord.). In: Actas de las I Jornadas de Jóvenes en Investigación Aqueológica. (Madrid, 3-5 septiembre de 2008). Dialogando con la cultura material, vol. I, pp. 135-140.

De los Arcos, S., Gallego, N., Gil Ortiz, C., González García, I., Yravedra, J., 2010. E nivel 4 (arcillas) del yacimiento paleolítico del Estanque de Tormentas de Butarque (Villaverde, Madrid). In: Actas de las $\mathrm{V}$ jornadas de patrimonio arqueológico en la Comunidad de Madrid, pp. 287-291. Celebradas en el Museo Arqueológico Regional de la Comunidad de Madrid del 12-14 de noviembre de 2008. Alcalá de Henares. Madrid.

Dobosi, V.T., 2001. Ex Proboscideis-Proboscidean remains as raw material at four Palaeolithic sites, Hungary. In: Cavarretta, G., Gioia, P., Mussi, M., Palombo, M.R. (Eds.), The World of Elephants. Proceedings of the First International Congress Consiglio Nazionale delle Ricerche, Rome, pp. 429-431.

Domínguez Alonso, R.M., De los Arcos Fernández, S., Ruiz Zapata, B., Gil García, M.J. 2007. Terraza Compleja de Butarque en Villaverde. In: Póster IV Jornadas sobre Patrimonio Arqueológico de la Comunidad de Madrid. Celebradas en el Museo Arqueológico Regional de la Comunidad de Madrid en 2007. Alcalá de Henares. Madrid.

Domínguez Alonso, R.M., De los Arcos Fernández, S., Ruiz Zapata, B., Gil García, M.J. 2009. Nuevos datos sobre la Terraza Compleja de Butarque en Villaverde Bajo. In: IV Jornadas sobre Patrimonio Arqueológico de la Comunidad de Madrid. Celebradas en el Museo Arqueológico Regional de la Comunidad de Madrid en 2007. Alcalá de Henares. Madrid, pp. 339-343.

Domínguez-Rodrigo, M., 2008. Butchery and kill sites. In: Pearsall, D.M. (Ed.) Encyclopedia of Archaeology. Academic Press, New York, pp. 948-953.

Douglas-Hamilton, I., 1972. On the Ecology and Behaviour of the African Elephant (Unpublished D.Phil. thesis in Zoology). University of Oxford.

Duffy, K.J., Xiaohua, D., Shannon, G., Slotow, R., Page, B., 2011. Movement patterns of African elephant (Loxodonta africana) in different habitat types. South African Journal of Wildlife Research 41 (1), 21-28.

El Zaatari, S., Frederick, E.G., Ungar, P.S., Hublin, J.J., 2011. Ecogeographic variation in Neandertal dietary habits: evidence from occlusal molar microwear texture analysis. Journal of Human Evolution 61, 411-424.

Forman, R.T., 1995. Land Mosaics. The Ecology of Landscapes and Regions. Cambridge University Press.

Fosse, P., 1998. Les probóscides dans les sites archéologiques de plein air paléolithiques origine antropologique ou naturalle?. In: XVIII Rencontres international d'Archeologie et d'hisire d'Antibes. Octubre, 1997, pp. 105-117.

Freeman, L.G., 1994. Torralba and Ambrona: a review of discoveries. In: Corruccini, R.S., Ciochon, R.L. (Eds.), Integrative Paths to the Past. Prentice Hall, Englewood Cliffs, New Jersey, pp. 597-637.

Frison, G.C., 1989. Experimental use of Clovis Weaponry and tools on African elephants. American Antiquity 54, 766-784.

Frison, G.C., Todd, L.C., 1986. The Colby Mammoth Site. University of New Mexico Press, Albuquerque.

Gaibar Puertas, C. 1974. Descubrimiento de la terraza wüermiense en la margen izquierda del río Manzanares: aportaciones paleoclimáticas, nuevos restos y testimonios del madrileño hombre prehistórico y protohistórico. Estudios Geológicos XXX (2-3), 235-252.

Gamazo, M., 1982. Prospecciones en las terrazas de la margen derecha del río Manzanares (Getafe y Rivas-Vaciamadrid). Noticiario Arqueológico Hispánico $14,7-148$.

Gamazo, M. 2002. Las colecciones paleolíticas del Manzanares y del Jarama de Museo de San Isidro. In: Panera, J., Rubio Jara, S. (Eds.), Bifaces y elefantes. La investigación del Paleolítico Inferior en Madrid, Zona Arqueológica, 1, pp. 358 381.

Gamazo, M., Cobo, A., 1983. Desarrollo de las teorías sobre la edad y formación de las terrazas del Manzanares, pp. 63-81. Nuevas aportaciones. Homenaje al Profesor M. Almagro Basch I.

Gamble, C., 1999. The Palaeolithic Societies of Europe. Cambridge University Press, Cambridge.

Gaudzinski, S., 1996. On bovid assemblages and their consequences for the knowledge of subsistence patterns in the Middle Palaeolithic. Proceedings of the Prehistoric Society 62, 19-39.

Gaudzinski, S., 1999. Middle Palaeolithic bone tools from the open-air site Salzgitter-Lebenstedt (Germany). Journal of Archaeological Science 26, 125-141.
Gaudzinski, S., Kindler, 2012. Research perspectives for the study of Neandertal subsistence strategies based on the analysis of archaeozoological assemblages. Quaternary International 247, 59-68.

Gaudzinski, S., Roebroeks, W., 2000. Adults only. Reindeer hunting at the Middle Palaeolithic site Salzgitter Lebenstedt, Northern Germany. Journal of Human Evolution 38, 497-521.

Gaudzinski, S., Turner, E., Anzidei, A.P., Álvarez-Fernández, E., Arroyo-Cabrales, J., Cinq-Mars, J., Dobosi, V.T., Hannus, A., Johnson, E., Münzel, S.C., Scheer, A., Villa, P., 2005. The use of Proboscidean remains in every-day Palaeolithic life Quaternary International 126-128, 179-194.

Germonpré, M., Udrescu, M., Fiers, E., 2012. Possible evidence of mammoth hunting at the Neanderthal site of Spy (Belgium). Quaternary International. http://dx. doi.org/10.1016/j.quaint.2012.10.035.

Goren-Inbar, N., Lister, E., Werker, E., Chech, M., 1994. A butchered elephant skull and associated artifacts from the Acheulian site of gesher Benot Ya'Aqov, Israel. Paléorient 20 (1), 99-112.

Goy, J.L., Pérez-González, A., Zazo, C., 1989. Cartografía y Memoria del Cuaternario y Geomorfología, Hoja de Madrid (559). In: Mapa Geológico de España. Escala 1: 50.000. 2a Serie (MAGNA). IGME. Servicio de Publicaciones del Ministerio de Industria, Madrid.

Haggett, P., Cliff, A.D., Frey, A.E., 1977. Locational Analysis in Human Geography. E. Arnold, Londres.

Haynes, G., 1991. Mammoths, Mastodonts, and Elephants: Biology, Behavior, and the Fossil Record. Cambridge University Press, New York.

Haynes, G., 2001. Elephant landscapes; human foragers in a world of mammoths, Mastodonts, and elephants. In: Cavarretta, G., Giola, P., Mussi, M., Palombo, M.R. (Eds.), The World of Elephants: Proceedings of the 1st International Congress. Consiglio Nazionale delle Ricerche-Roma, Rome, pp. 571-576.

Haynes, G., 2006. Mammoth landscapes: good country for hunter-gatherers. Quaternary International 142-143, 20-29.

Haynes, G., 2012. Elephants (and extinct relatives) as earth-movers and ecosystem engineers. Geomorphology 157-158, 99-107.

Haynes, G., Krasinski, K.E., 2010. Taphonomic fieldwork in Southern Africa and its application in studies of the earliest peopling of North America. Journal of Taphonomy 8 (2-3), 181-202.

Hobley, C.W., 1903. Notes concerning the Eldorobo of Mau, British East Africa. Man 3. 33-34.

Hoffecker, J.F., 2002. Desolate Landscapes: Ice-Age Settlement in Eastern Europe. Rutgers University Press, New Brunswick.

Howell, F.C., 1966. Observations on the earlier phases of the European lower Paleolithic. American Anthropologist 68 (2), 88-201.

Janmart, J., 1952. Elephant hunting as practised by the Congo Pymies. American Anthropologist 54, 146-147.

Klein, R.G., 1999. The human career. Human Biological and Cultural Origins, second ed. The University of Chicago Press, Chicago and London.

Kolen, J., 1999. Hominids without homes: on the nature of Middle Paleolithic settlement in Europe. In: Roebroeks, W., Gamble, C. (Eds.), The Middle Paleolithic Occupation of Europe. University of Leiden Press, Leiden, pp. 139-175.

Kröger, K., Bogaard, P., v.d., Bittmann, F., Turner, E., 1991. Der Fundplatz KärlichSeeufer. Neue Untersuchungen zum Altpaläolithikum Rotim Rheinland. Jahrbuch des Römisch-Germanischen Zentralmuseums Mainz 35, 111-135.

Mania, D., 1990. Auf der Spuren der Urmenschen: die Funde von Bilzingsleben. Theiss, Berlin.

Mania, D., Thomae, M., Litt, T., Weber, T., 1990. Neumark - Gröbern. Beiträge zur Jagd des mittelpaläolitischen Menschen. In: Veröffentlichung des Landesmuseums für Vorgeschichte Halle. Deutscher Verlag der Wissenschaften, Berlin, p. 43.

Mania, D., Weber, T. (Eds.), 1986. Bilzingsleben III. Deutscher Verlag der Wissenschaften, Berlin.

Manzano, L., Expósito, A., Pérez-González, A., Soto, E., Sesé, C., Yravedra, J., RuizZapata, B., Millán, A., Benéitez, P., Torres, T., Mondéjar, J.A., Zarco, E., Sánchez, H., Citores, A., Ramos, M., Rodríguez, A., 2010. El yacimiento arqueo-paleontológico de E.D.A.R. CULEBRO 1 (Estación Depuradora de Aguas Residuales de la Cuenca Baja del Arroyo Culebro. In: Ministerio de Medio Ambiente. Confederación Hidrógráfica del Tajo. Actas de las V jornadas de patrimonio arqueológico en la Comunidad de Madrid. Celebradas en el Museo Arqueológico Regional de la Comunidad de Madrid del 12-14 de noviembre de 2008. Alcalá de Henares. Madrid, pp. 203-214.

Martos, J.A., 1998. Elefantes e intervención humana en los yacimientos de Pleistoceno Inferior y Medio de África y Europa. Trabajos de Prehistoria 55 (1), 19-38.

McNeil, P., Hills, L.V., Kooyman, B., Tolman, S.M., 2005. Mammoth tracks indicate a declining Late Pleistocene population in southwestern Alberta, Canada. Quaternary Science Reviews 24, 1253-1259.

Meléndez, B., Aguirre, E., 1958. Hallazgo de Elephas en la terraza media del río Manzanares (Villaverde, Madrid). Las Ciencias XXIII (4), 597-605.

Moncel, M.H., 2001. Microlithic Middle Paleolithic assemblages in central Europe and elephants remains. In: Cavarreta, G. (Ed.), Atti del $1^{\circ}$ Congreso International. Procedings in the $1^{\circ}$ st International Congress, La Terra degli elefanti (The World of Elephants), pp. 314-317.

Moss, C.J., 1982. Portraits in the Wild: Behavior Studies of East African Mammals. University of Chicago Press, Chicago.

Movius, H.L., 1950. A wooden spear of third Interglacial age from lower Saxony. Southwestern. Journal of Anthropology 6 (2), 139-142.

Mussi, M., 2005. Hombres y Elefantes en las latitudes medias: una larga convivencia. In: Santonja, M., Pérez-González, A. (Eds.), Los Yacimientos Paleolíticos 
de Ambrona y Torralba. Un siglo de investigaciones arqueológicas, Zona Arqueológica, vol. 5, pp. 396-417.

Mussi, M., Villa, P., 2008. Single carcass of Mammuthus primigenius with lithic artifacts in the Upper Pleistocene of northern Italy. Journal of Archaeological Science 35, 2606-2613.

Neruda, P., 2010. Economic behavior and mental capacity of Neanderthals. In: Ecce Homo. In Memoriam Jan Fridrich. Knižnice České společnosti archeologické, OPS, pp. 111-129.

Nowell, A., d'Errico, F., 2007. The art of taphonomy and the taphonomy of art: layer IV, Molodova I, Ukraine. Journal of Archaeological Method and Theory 14 (1), 1-26.

Ollé, A., 2005. Variabilitat i patrons funcionals en els sistemes tècnics de mode 2 . Anàlisi de les deformacions d'ús en els conjunts lítics del Riparo Esterno de Grotta Paglicci (Rigano Garganico, Foggia), Aridos (Arganda, Madrid) i GaleriaTN (Atapuerca, Burgos) (PhD dissertation). Universitat Rovira i Virgili <http:// www.tdx.cesca.es/TDX-0701105-120553/>.

Owen-Smith, R.N., 1987. Pleistocene extinctions: the pivotal role of megaherbivores. Paleobiology 13, 351-362.

Owen-Smith, R.N., 1988. Megaherbivores: the Influence of Very Large Body Size on Ecology. Cambridge University Press, Cambridge.

Owen-Smith, R.N. 1999. The interaction ofhumans, megaherbivores, and habitats in the late Pleistocene extinction event. In: MacPhee, R.D.E. (Ed.), Extinctions in Near Time: Causes, Contexts, and Consequences. Kluwer Academic/Plenum Publishers, New York, pp. 57-69.

Panera, J., Rubio-Jara, S., 2002. Bifaces y elefantes. La investigación del Paleolítico Inferior en Madrid. In: Zona Arqueológica, vol. 1, p. 510.

Patrocinio, M., Martínez-Navarro, B., Palmqvist, P., Ros-Montoya, S., Toro, I., Agustí, J., Sala, R., 2013. Homo vs. Pachycrocuta: earliest evidence of competition for an elephant carcass between scavengers at Fuente Nueva-3 (Orce, Spain). Quaternary International 295, 113-125.

Paunescu, A., 1992. Ripiceni-Izvor. Le Paléolithique et le Mésolithique (étude monographique). Préhistoire Européenne 1, 63-66.

Pérez-González, A., 1971. Estudio de los procesos de hundimiento en el valle del río Jarama y sus terrazas (nota preliminar). Estudios Geológicos XXVII (4), 317-324.

Pérez-González, A., 1994. Depresión del Tajo. In: Elorza, Gutiérrez (Ed.), Geomorfología de España, pp. 389-436 (Rueda).

Pérez-González, A., Rubio-Jara, S., Panera, J., Uribelarrea, D., 2008. Geocronología de la sucesión arqueoestratigráfica de Los Estragales en la Terraza Compleja de Butarque (Valle del río Manzanares, Madrid). Geogaceta 45, 39-42.

Pérez-González, A., Uribelarrea del Val, D., 2002. Geología del Cuaternario de los valles fluviales del Jarama y Manzanares en las proximidades de Madrid. In: Panera, J., Rubio-Jara, S. (Eds.), Bifaces y elefantes. La investigación del Paleolítico Inferior en Madrid, Zona Arqueológica, 1, pp. 303-317.

Portero, J., Pérez-González, A., 1990. Hoja y Memoria del Mapa Geológico de España, a escala 1:50.000. Alcalá de Henares, $n^{\circ}$ 560. Instituto Tecnológico y Geominero de España, Madrid.

Prado, C. de, 1864. Descripción Física y Geográfica de la Provincia de Madrid, 2ạ ed. Junta General de Estadística, Madrid. 1975, (Colegio de Ingenieros de Caminos, Canales y Puertos. Madrid).

Priego, C., Quero Castro, S., Gamazo, M., Gálvez, P., 1979. Prehistoria y Edad Antigua en el área de Madrid. In: Catálogo de la Exposición: Madrid hasta 1875. Testimonios de su historia, pp. 46-81.

Rabinovich, R., Ackermann, O., Aladjem, E., Barkai, R., Biton, R., Milevski, I., Solodenko, N., Marder, O., 2012. Elephants at the Middle Pleistocene Acheulian open-air site of Revadim Quarry, Israel. Quaternary International 276-277, 183197.

Radmilli, A.M., Boschian, G., 1996. Gli scavi a Castel di Guido. Il più antico giacimento di cacciatori nell'Agro Romano. ETS, Pisa, p. 306.

Reggiani, P., 2005. Gli astragali del mammut di Asolo (Treviso). In: Fiore, L. Malerba, G. Chilardi, S. (Eds.), Atti del 3 Convegno Nazionale di Archeozoologia. Studi di Paletnologia II. Museo Nazionale Preistorico Etnografico "Luigi Pigorini", Roma, pp. 141-144.

Reggiani, P., Sala, B., 1992. I mammut del Veneto. In: Memorie Scienze Geologica, vol. XLIV, pp. 171-191.

Richards, M.P., Trinkaus, E., 2009. Isotopic evidence for the diets of European Neanderthals and early modern humans. Proeedings of the National Academy of Sciences of the United States of America 106, 16034-16039.

Robinson, G.S., Burney, D.A., Burney, L.P., 2003. A palynological approach to the study of megaherbivore extinction in the Hudson Valley. In: Paper Presented at the $3^{\text {rd }}$ International Mammoth Conference. 3rd International Mammoth Conference, 2003, Program and Abstracts. Government of the Yukon, p. 132. Palaeontology Program, Occasional Papers in Earth Science 5.

Ros-Montoya, S., 2010. Los proboscídeos del Plio-Pleistoceno de las Cuencas de Guadix-Baza y Granada (Tesis Doctoral). Universidad de Granada http://hera. ugr.es/tesisugr/18685316.pdf.

Rubio-Jara, S., 2011. El paleolítico en el valle del río Manzanares (Madrid). Caracterización geoarqueológica de depósitos pleistocenos y estudio tecnoeconómico de la industria lítica (Tesis Doctoral inédita). Universidad Nacional de Educación a Distancia.

Rus, I., 1989. El paleolítico inferior en el valle del Manzanares. Raña 7, 33-34.

Rus, I., Enamorado, J., 1991. Flint suply in the Manzanares valley: the acheulian site of Arriaga (Madrid, Spain). In: VI Flint International Symposium (Granada), pp. 569-576.

Rus, I., Querol, M.A., 1981. El arenero de Oxígeno: bifaces, hendedores y triedros conservados en el Museo Arqueológico Nacional. Trabajos de Prehistoria 38, 39-67.
Rus, I., Santonja, M., 2011. Arriaga IIa. In: Santonja, M. (Ed.), Los Exploradores de los Valles. Comunidad de Madrid, Madrid, pp. 56-57.

Rus, I., Vega Toscano, G., 1984. El yacimiento de Arriaga II: problemas de una def inición actual de los suelos de ocupación. In: Primeras Jornadas de Metodología e Investigación Prehistórica (Soria, 1981). Ministerio de Cultura, pp. 387-404.

Saccà, D., 2012. Taphonomy of Palaeloxodon antiquus at Castel di Guido (Rome, Italy): Proboscidean carcass exploitation in the Lower Palaeolithic. Quaternary International 276-277, 27-41.

Saladié, P., Vallverdú, J., Bennàsar, Ll., Cabanes, D., Mancha, E., Menéndez, L., Blain, H., Ollé, A., Mosquera, M., Vilalta, J., Cáceres, I., Expósito, I., Estéban, M. Huguet, R., Rosas, A., Solé, A., López-Polín, L., García, A.B., Martínez, B., Carbonell, E., Capdevila, R., 2008. Resultats preliminars del nivell 2 del sodenig al Centre de Convencions del barranc de la Boella. Cota Zero 23, 13-19.

Santonja, M., López Martínez, N., Pérez-González, A., 1980. Ocupaciones achelenses en el valle del Jarama. In: Arqueología y Paleontología, vol. I. Diputación Provincial de Madrid.

Santonja, M., Pérez-González, A., 2005. Arqueología y elefantes en el Pleistoceno Medio de la Península Ibérica. In: Santonja, M., Pérez-González, A. (Eds.), Los yacimientos Paleolíticos de Ambrona y Torralba (Soria). Un siglo de investigaciones arqueológicas, Zona Arqueológica, 5, pp. 382-395.

Santonja, M., Pérez-González, A., Vega Toscano, G., Rus, I., 2001. Elephants and stone artifacts in the Middle Pleistocene terraces of the Manzanares river (Madrid, Spain). In: The World of Elephants. Proceedings of the I' International Congress. Roma, 16-20 October, 2001, pp. 597-601.

Santonja, M., Querol, M.A., 1980. Las industrias achelenses en la región de Madrid In: Santonja, M., López, N., Pérez- González, A. (Eds.), Ocupaciones achelenses en el valle del Jarama, Arqueología y Paleontología, vol. I, pp. 29-48.

Schreve, D.C., 2006. The taphonomy of a Middle Devensian (MIS 3) vertebrate assemblage from Lynford, Norfolk, UK, and its implications for Middle Palaeolithic subsistence strategies. Journal of Quaternary Science 21, 543-556.

Scott, K., 1980. Two hunting episodes of Middle Palaeolithic Age at La Cotte de Saint-Brelade. Jersey (Channel Islands). World Archaeology 12 (2), 137-152.

Scott, J., 1986. The bone assemblages of layers 3 and 6. In: Callow, P., Cornford, J.M (Eds.), La cotte de Saint Brelade 1961-1978: Excavations by C.B.M. McBurney. Cambridge Geobooks, pp. 159-184.

Scott, K., 2001. Late Middle Pleistocene mammoths and elephants of the Thames valley Oxfordshire. In: Cavarretta, G., Gioia, P., Mussi, M., Palombo, M.R. (Eds.) The World of Elephants. Proceedings of the First International Congress. Consiglio Nazionale delle Ricerche, Rome, pp. 247-254.

Segre, A., Ascenzi, A., 1984. Fontana Ranuccio: Italy's earliest Middle Pleistocene hominidsite. Current Anthropology 25, 230-233.

Sesé, C., López Martínez, N., 2013. Nuevos datos paleontológicos del Pleistoceno en el valle del Manzanares (Madrid, España): los micromamíferos del yacimiento del Arenero de Arriaga. Estudios Geológicos (in press).

Sesé, C., Rubio-Jara, S., Panera, J., Pérez-González, A., 2011. Micromamíferos de Pleistoceno Superior del yacimiento de PRERESA en el valle del Manzanares y su contribución a la reconstrucción paleoambiental de la cuenca de Madrid durante el Pleistoceno. Estudios Geológicos 67 (2), 471-494.

Sesé, C., Sevilla, P., 1996. Los micromamíferos del Cuaternario peninsular español. Cronoestratigrafía e implicaciones biogeográficas. Revista Española de Paleonología, 278-287 n extraordinario.

Sesé, C., Soto, E., 2000. Vertebrados del Pleistoceno de Madrid. In: Morales, J. (Ed.), Patrimonio paleontológico de la Comunidad de Madrid, Arqueología, Paleontología y Etnografía, vol. 6, pp. 215-243.

Sesé, C., Soto, E., 2002. Catálogo de los yacimientos de Vertebrados del Pleistoceno en las terrazas de los ríos Jarama y Manzanares. In: Panera, J., Rubio-Jara, S. (Eds.), Bifaces y elefantes. La investigación del Paleolítico Inferior en Madrid, Zona Arqueológica, vol. 1, pp. 430-457.

Sesé, C., Soto, E., 2002b. Vertebrados del Pleistoceno del Jarama y Manzanares. In: Panera, J., Rubio-Jara, S. (Eds.), Bifaces y elefantes. La investigación del Paleolítico Inferior en Madrid, Zona Arqueológica, vol. 1, pp. 318-337.

Shannon, G., Matthews, G.W.S., Page, B.R., Parker, G.E., Smith, R.J., 2009. The affects of artificial water availability on large herbivore ranging patterns in savanna habitats: a new approach based on modelling elephant path distribution. Diversity and Distributions 5, 776-783.

Shannon, G., Page, B., Slotow, R., Duffy, K.J., 2006. African elephant home range and habitat selection in Pongola Game Reserve, South Africa. African Zoology 41, 37-44.

Silva, P.G., 2003. El valle inferior del Manzanares (Cuenca de Madrid, España) Volumen en Homenaje a D. Manuel Hoyos. Estudios Geológicos 59, 107-131.

Silva, P.G., López Recio, M., Cuartero, F., Baena, J., Tapias, F., Manzano, I., Martín, D. Morín, J., Roquero, E., 2012a. Contexto geomorfológico y principales rasgos tecnológicos de nuevos yacimientos del Pleistoceno Medio y Superior en el Valle Inferior del Manzanares (Madrid, España). Estudios Geológicos 68, 58-89.

Silva, P.G., López-Recio, M., Tapias, F., Roquero, E., Morín, J., Rus, I., CarrascoGarcía, P., Giner-Robles, J.L., Rodríguez-Pascua, M.A., Pérez-López, R., 2012b. Stratigraphy of the Arriaga Palaeolithic sites. Implications for the geomorphological evolution recorded by thickened fluvial sequences within the Manzanares River valley (Madrid Neogene Basin, Central Spain). Geomorphology. http://dx.doi.org/10.1016/j.geomorph.2012.10.019.

Slimak, L., Svendsen, J.I., Mangerud, J., Plisson, H., Heggen, H.P., Brugère, A. Pavlov, P.Y., 2011. Late Mousterian persistence near the Arctic Circle. Science $332,841-845$.

Smith, G.M., 2012. Middle Palaeolithic subsistence: the role of hominins at Lynford, Norfolk, UK. Quaternary International 252, 68-81. 
Soto, E., Sesé, C., 1991. Restos de grandes mamíferos del Pleistoceno del arenero del arroyo del Culebro (Getafe, Madrid). Estudios de Prehistoria y Arqueología Madrileñas 7, 7-27.

Sousa, M.F., Figueiredo, S.M., 2001. The Pleistocene elephants of Portugal. In: Cavarreta, G., et al. (Eds.), Proceedings of the I Int. Congress "The World of Elephants". Comune di Roma, C.N.R, Ministero per i Beni e le Attività Culturali, Università di Roma, Roma.

Speth, J.D., 1991. Nutritional constraints and Late Glacial adaptive transformations: the importance of non-protein energy sources. In: Barton, N., Roberts, A.J., Roe, D.A. (Eds.), The Late Glacial in North-west Europe: Human Adaptation and Environmental Change at the End of the Pleistocene, vol. 77, pp. 169-178.

Stokke, S., Du Toit, J.T., 2002. Sexual segregation in habitat use by elephants in Chobe National Park, Botswana. African Journal of Ecology 40, 360-371.

Stringer, C., Gamble, C., 1993. Search of the Neandertals: Solving the Puzzle of Human Origins. Thames and Hudson, New York.

Sukumar, R., 1989. The Asian Elephant: Ecology and Management. Cambridge University Press, Cambridge.

Surovell, T.A., Waguespack, N.N., 2008. How many elephant kills are 14? Quaternary International 191, 82-97.

Svoboda, J., Péan, S., Wojtal, P., 2005. Mammoth bone deposits and subsistence practises during Mid-Upper Palaeolithic in Central Europe: three cases from Moravia and Poland. Quaternary International 126-128, 209-221.

Thieme, $\mathrm{H}$. 2005. The lower palaeolithic art of hunting the case of Schöningen 13 II 4, lower Saony, Germany. In: Gamble, C., Porr, M. (Eds.), The Hominid Individual in Context: Archaeological Investigations of Lower and Middle Palaeolithic Landscapes, Locales, and Artefacts. Routledge, New York, pp. 115-132.

Thieme, H., Veil, S., 1985. Neue Untersuchungen zum eemzeitlichen ElefantenJagdplaz Lehringen, vol. 36. Die Kunde N. F, Ldkr. Verden, pp. 11-58.

Tode, A., 1954. Mammut jager vor 100,000 Jahren (Brunswick).

Trilles, P., 1932. Les Pygmees de la Foret Equatoriale. Librairie Bloud et Gay, Paris.

Turner, E., 1997. Ariendorf-Quaternary deposits and Palaeolithic excavations in the Karl Schneider gravel pit. Jahrbuch des Römisch-Germanischen Zentralmuseums Mainz 44, 3-191.

Vallverdú, J., Saladié, P., Bennàsar, L, Cabanes, D., Mancha, E., Menéndez, L, Blain, H., Ollé, A., Vilalta, J., Mosquera, M., Cáceres, I., Expósito, I., Esteban, M., Huguet, R. Rosas, A., Solé, À., López-Polín, L., Martinell, J., García-Garbo, A., MartínezNavarro, B., Agustí, J., Ros-Montoya, S., Carbonell, E., Capdevila, R., 2009. El barranc de la Boella de la Canonja (Tarragonès) revisitat en la intervenció arqueológica preventiva de l'any 2007. Tribuna d'Arqueologia, 7-28, 2008-2009.
Valoch, K., 1988. Die Erforschung der Kulna-Höhle 1961-1976, Band 24. Anthropos, Brnos.

Vega Toscano, L.G., Raposo, L., Santonja, M., 1999. Environments and settlement in the Middle Palaeolithic of the Iberian Peninsula. In: Roebrooks, W., Gamble, C. (Eds.), The Middle Palaeolithic Occupation of Europe. University of Leiden, pp. 23-48.

Venzo, S., 1977. I depositi quaternari e del Neogene superiore nella bassa valle del Piave da Quero al Montello e del Paleopiave nella valle del Soligo. In: Memoire Instit. Geol. Mineral. dell'Univ. Padova, vol. 30, pp. 1-62.

Verneuil, E. de, Lartet, E., 1863. Note sur un sílex taillé trouvé dans le diluvium des environs de Madrid. Bulletin de la Societé Géologique de France XX (2ème série), 698-702 (Paris).

Villa, P., 1990. Torralba and Áridos: elephant exploitation in middle Pleistocene Spain. Journal of Human Evolution 19, 299-309.

Villa, P., Anzidei, A.P., Cerilli, E., 1999. Bones and Bone Modifications at La Polledrara, a Middle Pleistocene Site in Italy. The Role of Early Humans in the Accumulation of European Lower and Middle Palaeolithic Bone Assemblages. In: Monographien des Römisch-Germanischen Zentralmuseums, Mainz, vol. 42, pp. 197-206.

Villa, P. Lenoir, M., 2009. Hunting and hunting Weapons of the lower and middle Paleolithic or Europe. In: Hublin, J.-J., Richards, M.P. (Eds.), The Evolution of Hominin Diets. Integrating Approaches to the Study of Paleolithic Subsistence. Springer, pp. 59-86.

Villa, P., Soto, E., Pérez-González, A., Santonja, M., Mora, R., Parcerisas, O. Sese, C., 2005. New data from Ambrona (Spain), closing the hunting versus scavenging debate. Quaternary International 126-128, 223-250.

Weber, T., 2000. The Eemian Elephas antiquus finds with artifacts from Lehringen and Gröbern: are they really killing sites? Anthropologie et Préhistoire 111, $177-185$.

Yravedra, J., Domínguez-Rodrigo, M., Santonja, M., Pérez-González, A., Panera, J. Rubio-Jara, S., Baquedano, E., 2010. Cut marks on the Middle Pleistocene elephant carcass of Áridos 2 (Madrid, Spain). Journal of Archaeological Science 37, 2469-2476.

Yravedra, J. Rubio-Jara, S, Panera, J. Uribelarrea, D, Pérez-González, A, 2012. Elephants and subsistence. Evidence of the human exploitation of extremely large mammal bones from the Middle Palaeolithic site of PRERESA (Madrid, Spain). Journal of Archaeological Science 39, 1063-1071.

Zbyszewski, G., 1943. Les eléphants quaternaires du Portugal. Comunicações dos Serviços Geológicos de Portugal 24, 71-89. 